WIPP/DOE - 069

Revision 3

$$
\begin{aligned}
& \text { UC - } 70 \\
& \text { Received b; OSth } \\
& \text { MAR O }{ }_{1989}
\end{aligned}
$$

\title{
TRU Waste Acceptance Criteria for the Waste Isolation Pilot Plant
}

\section{January 1989}

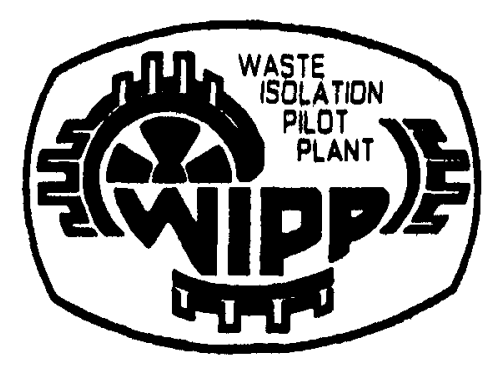

WASTE ISOLATION PILOT PLANT 


\section{DISCLAIMER}

This report was prepared as an account of work sponsored by an agency of the United States Government. Neither the United States Government nor any agency Thereof, nor any of their employees, makes any warranty, express or implied, or assumes any legal liability or responsibility for the accuracy, completeness, or usefulness of any information, apparatus, product, or process disclosed, or represents that its use would not infringe privately owned rights. Reference herein to any specific commercial product, process, or service by trade name, trademark, manufacturer, or otherwise does not necessarily constitute or imply its endorsement, recommendation, or favoring by the United States Government or any agency thereof. The views and opinions of authors expressed herein do not necessarily state or reflect those of the United States Government or any agency thereof. 


\section{DISCLAIMER}

Portions of this document may be illegible in electronic image products. Images are produced from the best available original document. 
DE89 007452

TRU WASTE ACCEPIANCE CRTIERIA

FOR THE

WASTE ISOLATION PIIOT PLANT

JANUARY 1989

WESTINGHOUSE ELECIRIC CORPORATION

WASTE ISOLATION PIIOT PLANT

MANAGEMENT AND OPERATING CONIRACTOR

\section{DISCLAIMER}

This report was prepared as an account of work sponsored by an agency of the United States Government. Neither the United States Government nor any agency thereof, nor any of their employees, makes any warranty, express or implied, or assumes any legal liability or responsibility for the accuracy, completeness, or usefulness of any information, apparatus, product, or process disclosed, or represents that its use would not infringe privately owned rights. Reference herein to any specific commercial product, process, or service by trade name, trademark, manufacturer, or otherwise does not necessarily constitute or imply its endorsement, recommendation, or favoring by the United States Government or any agency thereof. The views and opinions of authors expressed herein do not necessarily state or reflect those of the United States Government or any agency thereof. 
Page

TABLE OF CONTENIS

IIST OF FIGURES . . . . . . . . . . . . . . . . . . ii

IIST OF TABLES . . . . . . . . . . . . . . . . . ii

FOREWORD .......................... . . . 1 . . . . . .

1.0 INIRODUCTION ......................... 1

2.0 DEFTNITIONS AND SUMMARY ............... 3

2.1 DEFTNITIONS. . . . . . . . . . . 3

2.2 SUMMARY. . . . . . . . . . . . . 7

3.0 WASTE CONTATNER REQUIREMENTS . . . . . . . . . . . 14

3.1 CRITERION: WASTE CONTATNERS . . . . . . . . 14

3.2 CRTIERION: WASTE PACKAGE SIZE . . . . . . . 16

3.3 CRITIERTON: WASTE PACKAGE HANDLTNG ...... 17

4.0 WASTE FORM REQUIREMENIS . . . . . . . . . . . . 19

4.1 CRTIERTON: IMMOBILIZATION ......... 19

4.2 CRTIERTON: IIQUID WASTES . . . . . . . . 22

4.3 CRTTERTON: PYROPHORIC MATERIAIS . . . . . . 23

4.4 CRITERTON: EXPLOSTVES AND COMPRESSED GASES • . 25

4.5 CRITERION: RADIOACTIVE MIXED WASTES . . . . . 26

4.6 CRITERION: SPECIFIC ACITVITY OF WASTE . . . . . 30

4.7 DISCUSSION: COMBUSTIBILTTY . . . . . . . 31

5.0 WASTE PACKAGE REQUIREMENTS . . . . . . . . . . 34

5.1 CRTTERTON: WASTE PACKAGE WEIGHT . . . . . . 34

5.2 CRITERION: NUCIEAR CRITICAITTY . . . . . 35

5.3 CRITERION: PU-239 EQUTVALENT ACTIVITY . . . . 38

5.4 CRTIERION: SURFACE DOSE RATE . . . . . . . 40

5.5 CRITIERION: SURFACE CONIAMINATION . . . . . . 42

5.6 CRITERION: THERMAL POWER ......... 43

5.7 CRITERION: GAS GENERATION . . . . . . . . 44 
Page

5.0 WASTE PACKAGE REQUIREMENTS (Continued)

5.8 CRITIERTON: IABETING . . . . . . . . . . . 49

5.9 CRITERION: DATA PACKAGE/CERTIFICATION . . . . . 50

5.10 CRITERION: RH TRU ACTIVITY CONCENTRATION . . . . 55

6.0 REFERENCES $\ldots \ldots 6$

APPENDIX A: MISSION AND DESCRIPTION OF WASTE ISOIATION

PILOT PLANT . . . . . . . . . . . . A A-1

\section{ITST OF FIGURES}

Figure No.

Title

Page

A-1 Surface Structures and Plant Layout . . . . . . A-5

A-2 CH Emplacement Flow Diagram . . . . . . . . . A-6

A-3 RH Emplacement Flow Diagram .......... A-7

A-4 Waste Isolation Pilot Plant Underground Layout. . . A-8

\section{LIST OF TABLES}

Table No.

Title

Page

1

WIPP WAC Summary 
FOREWORD

Criteria for the acceptance of unclassified transuranium element (TRU) contaminated wastes at the Waste Isolation Pilot Plant (WIPP) were documented by the Waste Acceptance Criteria Steering Committee in its May 1980 report (Reference 1).

Revisions 1 and 2 reflected the results of ongoing project activities, including consultations with the Erviromental Evaluation Group (EEG) of the State of New Mexico and the Joint Integration Office (JIO). The revisions to the criteria presented were consistent with the original intent of the Waste Acceptance Criteria (WAC) as presented in Reference 1.

This issue, Revision 3, reflects further ongoing project activities, interactions with the above-mentioned groups and other TRU program participants. These revisions are also consistent with the original intent of the WAC.

As this document has been completely reorganized, sidebarring has been omitted. 


\subsection{INIRODUCIION}

This document is intended to delineate the criteria by which unclassified waste will be accepted for emplacement at the Waste Isolation Pilot Plant (WIPP) in southeastern New Mexico and describe the bases upon which these criteria were established. These criteria are not intended to be specifications but rather limits that will allow waste generating and shipping sites to develop their own procedures and specifications for preparation of TRU waste for shipment to the WIPP. These criteria will also allow waste generating sites to plan future facilities for waste preparation that will produce TRU waste forms compatible with WIPP waste emplacement and isolation requirements.

These criteria only apply to contact-handled (CH) and remote-handled (RH) transuranic (TRU) waste forms and are not intended to apply to beta-gamma wastes, spent fuel, high-level waste $(H L W)$, low-level waste (LIW), low specific activity (ISA) waste, or forms of radicactive waste for experimental purposes. Specifications for receipt of experimental waste forms will be prepared by the responsible projects in conjunction with the staff of the WIPP project at a later date. In addition, these criteria only apply to waste emplaced in bedded rock salt. Technical bases for these criteria may differ significantly from those for other host rocks.

The technical objectives of this document can be summarized in three areas:

1. To provide waste acceptance criteria that will permit demonstrating the safe disposal of TRU radicactive waste at WIPP.

2. To document the technical justification for TRU waste acceptance criteria for bedded salt as the host medium.

3. To provide quantitative guidelines, in the form of criteria, that can be used by waste form developers in designing TRU waste processing systems that will produce TRU waste forms acceptable for geologic disposal in bedded salt. 
The WIPP Project will comply with Titles 10 and 49 of the code of Federal Regulations (CFR), as applicable. The WIPP WAC are additional limits that are to be used as a supplement to the applicable CFR regulations. All applicable state and federal regulations relating to shipments of radioactive or hazardous materials will apply to shipments to the WIPP.

Requests for exception to one or more of these criteria may be submitted to WIPP for approval. Specific WIPP approval is required prior to shipping a waste package which does not meet these criteria, or it will not be accepted at the gate. All requests will be considered on a case-by-case basis. Blanket exemptions to any criterion will not be approved. Each request for exception must be submitted with sufficient justification to convince the WIPP reviewers that there is no significant personnel hazard, no significant potential increase in exposure to the public, and no significant impact to WIPP operational, safety, and envirormental parameters. 


\subsection{DEFINITIONS AND SUMMARY}

\subsection{DEFINITIONS}

\section{Contact-Handled TRU Waste}

Transuranic waste materials that are packaged in such a way that the dose rate at the surface of the waste package is not greater than $200 \mathrm{mRem} / \mathrm{hr}$.

\section{Combustible Materials}

Combustible materials are those materials which will sustain combustion in atmospheric air when exposed to an ignition source of 1475 degree Fahrenheit (800 degree celsius) for a period of 5 minutes.

\section{Compressed Gas}

Compressed gases are those materials defined as such by 49 CFR 173, Subpart G.

\section{Corrosive Materials}

Corrosive materials are those defined as such by 49 CFR 173, subpart F.

\section{Explosive Materials}

Explosive materials are those defined as such by 49 CFR 173, Subpart C.

\section{Free Liquid}

Iiquid that is not sorbed into a host material such that it could spill or drain from its container. 


\section{Immobilized Materials}

Materials that are fixed in a matrix such as glass, ceramic, cement, concrete, etc.

\section{Overpack}

An enclosure that is used to provide protection or convenience in handling of a package.

\section{Pu-239 Equivalent Activity}

The Pu-239 equivalent activity (AM), expressed in $\mathrm{PE}-\mathrm{C} i$, is the sum of the radionuclide activity which can be characterized by the expression:

$$
\mathrm{AM}=\sum_{i=1}^{\mathrm{K}} \frac{\mathrm{AF}_{i}}{\mathrm{AF}_{i}}
$$

where $K$ is the number of radionuclides, $A_{i}$ is the activity of radionuclide $i$ (in curies), and $\mathrm{WF}_{i}$ (a unitless number) is the $\mathrm{PE}-\mathrm{C} i$ weighting factor for radionuclide $i . ~ W F_{i}$ is defined by the ratio

$$
W F_{i}=\frac{E_{0}}{E_{i}}
$$

where $\mathrm{E}_{0}(\mathrm{rem} / \mu \mathrm{Ci})$ is the 50-year effective whole body dose commitment due to the inhalation of Pu-239 particulates with a $1.0 \mu \mathrm{m}$ Activity Median Aerodynamic Diameter (AMAD) and a weekly (W) pulmonary clearance class, and $E_{i}$ (rem $/ \mu \mathrm{Ci}$ ) is the 50-year effective whole body dose commitment due to the inhalation of radionuclide $i$ particulates with a $1.0 \mu \mathrm{m} \mathrm{AMAD}$ and the pulmonary clearance class resulting in the highest 50-year effective whole body dose commitment.

The value of $\mathrm{E}_{\mathrm{O}}$ and $\mathrm{E}_{\mathrm{i}}$ may be obtained from DOE/WIPP 87-014 (Reference 17). 


\section{Pu-239 Fissile Gram Equivalent}

The amount of Pu-239 which would produce the equivalent $\mathrm{K}_{\text {eff }}$ as that determined for the fissile material in the container (assuming all containers are in an optimally moderated infinite array) is called the Pu-239 fissile gram equivalent.

For materials other than Pu-239, U-235, and U-233 which shall be treated as equivalent, fissile equivalents shall be obtained using ANSI/ANS-8.15-1981 (Reference 4).

\section{Byrophoric Materials}

Pyrophoric materials are defined as those which may ignite spontaneously under the ambient conditions of shipment or storage in the WIPP. A comprehensive listing of many of these materials is found in 49 CFR 173, Subparts D and $E$.

\section{Radioactive Mixed Waste}

Radicactive mixed waste is radicactive waste that also contains hazardous materials as listed in 40 CFR 261, subparts $C$ and $D$.

\section{Remote-Handled TRU Waste}

Transuranic waste materials packaged such that the dose rate at the surface of the waste package is greater than $200 \mathrm{mRem} / \mathrm{hr}$, but not greater than 1000 Rem/hr.

\section{Short Term}

The period of time which includes loading waste packages into the transportation system, time in transit, and time in processing through the WIPP underground emplacement is called short term. This period does not include the WIPP five year retrieval decision period. 


\section{TRU Waste}

TRU waste, for the WIPP, is defined as defense waste contaminated with certain alpha-emitting radionuclides of atomic number greater than 92 and half-lives greater than 20 years in concentrations greater than 100 nanocuries per gram, as implemented by DOE Order 5820.2A.

\section{Waste Container}

A waste container is the disposable containment vessel for waste materials, including any integral liner or shielding materials, that is intended for emplacement at the WIPP. In the case of contaminated, damaged, leaking, or breached containers, any overpack shall be considered the container, and the original container shall be considered part of the waste.

\section{Waste Form}

Waste form refers to physical types of waste such as sludges, solids, organics, etc.

\section{Waste Package}

A waste package is the TRU waste material, any loose liner materials, and the waste container that is intended to be handled and emplaced at the WIPP.

\section{Waste Package Assembly}

An assembly of waste packages, such as a seven-pack of drums, that is intended to be handled and emplaced as a single unit by the WIPP waste handling system. 
Waste Volume Percent

The waste material volume, excluding entrapped void spaces, of one waste form, compared to the total volume of all waste forms within that package but not compared to the package volume.

\subsection{SUMMARY}

Table 1 shows a summary of the Waste Acceptance Criteria for both $\mathrm{CH}$ and $\mathrm{RH}$ TRU waste. 


\begin{tabular}{|c|c|c|}
\hline WAC & CONTACT-HANDLED & REMOTE-HANDLED \\
\hline $\begin{array}{c}\text { WASTE } \\
\text { CONTAINERS }\end{array}$ & $\begin{array}{l}\text { Waste containers for emplacement at the WIPP shall be } \\
\text { noncombustible and meet all the applicable requirements of } \\
49 \text { CFR } 173.412 \text { for Type A packaging. Waste containers of } \\
\text { various sizes shown to meet DOT Type A requirements by the } \\
\text { methods detailed in MLM } 3245 \text { are acceptable to WIPP. In } \\
\text { addition, they shall have a design life of at least } 20 \text { years } \\
\text { from the date of certification. } \\
\text { Any waste containers that appear to be bulged or otherwise } \\
\text { damaged shall be repackaged or overpacked in a container } \\
\text { meeting the above requirements. }\end{array}$ & $\begin{array}{l}\text { Remote-handled TRU waste containers shall be } \\
\text { noncombustible and meet, as a minimum, the } \\
\text { structural requirements and design conditions } \\
\text { for Type A packaging contained in } 49 \text { CFR } \\
173.412 \text {. Due to the special characteristic } \\
\text { and application of the RH TRU canister, the } \\
\text { compression test requirement of } 49 \text { CFR } 173.465 \\
\text { (d) is not applicable. In addition, all RH } \\
\text { waste containers shall be certified to a } \\
\text { WIPP-approved specification to have a design } \\
\text { life of at least } 20 \text { years from the date of } \\
\text { certification. }\end{array}$ \\
\hline $\begin{array}{l}\text { WASTE } \\
\text { PACKAGE } \\
\text { SIZE }\end{array}$ & $\begin{array}{l}\text { Contact-handled TRU waste packages or package assemblies } \\
\text { shall not exceed } 12 \times 8 \times 8.5 \text { feet }(3.7 \times 2.4 \times 2.6 \mathrm{~m}) \text { in } \\
\text { overall L } \mathrm{W} \text {. } \mathrm{H} \text { dimensions. }\end{array}$ & $\begin{array}{l}\text { Remote-handled TRU waste packages shall be no } \\
\text { larger than a nominal } 26 \text { inches }(0.66 \mathrm{~m}) \text { in } \\
\text { diameter with a maximum length of } 10 \mathrm{feet} \text {, } \\
1 \text { inch }(3.1 \mathrm{~m}) \text {, including the pintle. }\end{array}$ \\
\hline $\begin{array}{l}\text { WASTE } \\
\text { PACKAGE } \\
\text { HANDLING }\end{array}$ & $\begin{array}{l}\text { All waste packages shall be provided with cleats, offsets, } \\
\text { chimes, or skids for handling by means of fork trucks, } \\
\text { cranes, or similar handling devices. Lifting rings and } \\
\text { other auxiliary lifting devices on the packages, if provided, } \\
\text { shall be recessed, offset, or hinged in a manner which does } \\
\text { not inhibit stacking the packages. }\end{array}$ & $\begin{array}{l}\text { Remote-handled TRU waste packages shall be } \\
\text { equipped with an axial lifting pintle of a } \\
\text { design acceptable to the WIPP. The packages } \\
\text { shall have no other lifting devices. }\end{array}$ \\
\hline IMMOBILIZATION & $\begin{array}{l}\text { Powders, ashes and similar particulate waste materials shall } \\
\text { be immobilized if more than } 1 \text { weight percent of the waste } \\
\text { matrix in each package is in the form of particles below } 10 \\
\text { microns in diameter, or if more than } 15 \text { weight percent is in } \\
\text { the form of particles below } 200 \text { microns in diameter. }\end{array}$ & Same as contact-handled. \\
\hline $\begin{array}{l}\text { LIQUID } \\
\text { WASTES }\end{array}$ & $\begin{array}{l}\text { TRU waste shall not be in a free-liquid form. Minor liquid } \\
\text { residues remaining in well-drained bottles, cans, and other } \\
\text { containers are acceptable. }\end{array}$ & Same as contact-handled. \\
\hline
\end{tabular}




\begin{tabular}{|c|c|c|}
\hline WAC & CONTACT-HANDLED & REMOTE-HANDLED \\
\hline $\begin{array}{r}\text { PYROPHORIC } \\
\text { MATER IALS }\end{array}$ & $\begin{array}{l}\text { Pyrophoric materials, other than radionuclides, shall be } \\
\text { rendered safe by mixing with chemically stable materials (e.g. } \\
\text { concrete, glass, etc.) or processed to remove their hazardous } \\
\text { properties. No more than } 1 \text { percent by weight of the waste in } \\
\text { each package may be pyrophoric forms of radionuclides, and } \\
\text { these shall be generally dispersed in the waste. }\end{array}$ & Same as contact-handled. \\
\hline $\begin{array}{l}\text { EXPLOS IVES } \\
\text { AND } \\
\text { COMPRESSED } \\
\text { GASES }\end{array}$ & $\begin{array}{l}\text { TRU waste shall contain no explosives or compressed gases } \\
\text { as defined by } 49 \text { CFR } 173 \text {, Subparts C and G. }\end{array}$ & Same as contact-handled. \\
\hline $\begin{array}{l}\text { RADIOACTIVE } \\
\text { MIXED } \\
\text { WASTES }\end{array}$ & $\begin{array}{l}\text { TRU wastes shall contain no hazardous wastes unless they } \\
\text { exist as co-contaminants with transuranics. Waste packages } \\
\text { containing hazardous materials shall be identified with the } \\
\text { appropriate DOT label. TRU-contaminated corrosive materials } \\
\text { shall be neutralized, rendered noncorrosive, or packaged in a } \\
\text { manner to ensure container adequacy through the design } \\
\text { lifetime. Hazardous materials to be reported are listed in } \\
40 \mathrm{CFR} 261 \text {, Subparts } C \text { and } D \text {. }\end{array}$ & $\begin{array}{l}\text { TRU wastes shall contain no hazardous wastes } \\
\text { unless they exist as co-contaminants with } \\
\text { transuranics. TRU-contaminated corrosive } \\
\text { materials shall be neutralized, rendered non- } \\
\text { corrosive, or packaged in a manner to ensure } \\
\text { container adequacy through the design life- } \\
\text { time. Hazardous materials to be reported } \\
\text { are listed in } 40 \mathrm{CFR} 261 \text {, Subparts C and D. }\end{array}$ \\
\hline $\begin{array}{l}\text { SPECIFIC } \\
\text { ACTIVITY OF } \\
\text { WASTE }\end{array}$ & $\begin{array}{l}\text { For purposes of TRU waste certification, the } 100 \mathrm{nCi} / \mathrm{g} \text { TRU } \\
\text { waste limit shall be interpreted as } 100 \mathrm{nCi} \text { per } \mathrm{gram} \text { of waste } \\
\text { matrix. The weight of added,external shielding and the } \\
\text { containers (including any rigid liners) should be subtracted } \\
\text { prior to performing the nCi/g calculation. }\end{array}$ & Same as contact-handled. \\
\hline $\begin{array}{l}\text { WASTE } \\
\text { PACKAGE } \\
\text { WEIGHT }\end{array}$ & $\begin{array}{l}\text { Contact-handled TRU waste packages or package assemblies } \\
\text { shall weigh no more than } 21,000 \text { pounds }(9,550 \mathrm{~kg}) \text {. }\end{array}$ & $\begin{array}{l}\text { Remote-handled TRU waste packages shall weigh } \\
\text { no more than } 8,000 \text { pounds }(3,630 \mathrm{~kg}) \text {. }\end{array}$ \\
\hline
\end{tabular}




\begin{tabular}{|c|c|c|}
\hline WAC & CONTACT-HANDLED & REMOTE-HANDLED \\
\hline $\begin{array}{l}\text { NUCLEAR } \\
\text { CRITICALITY }\end{array}$ & 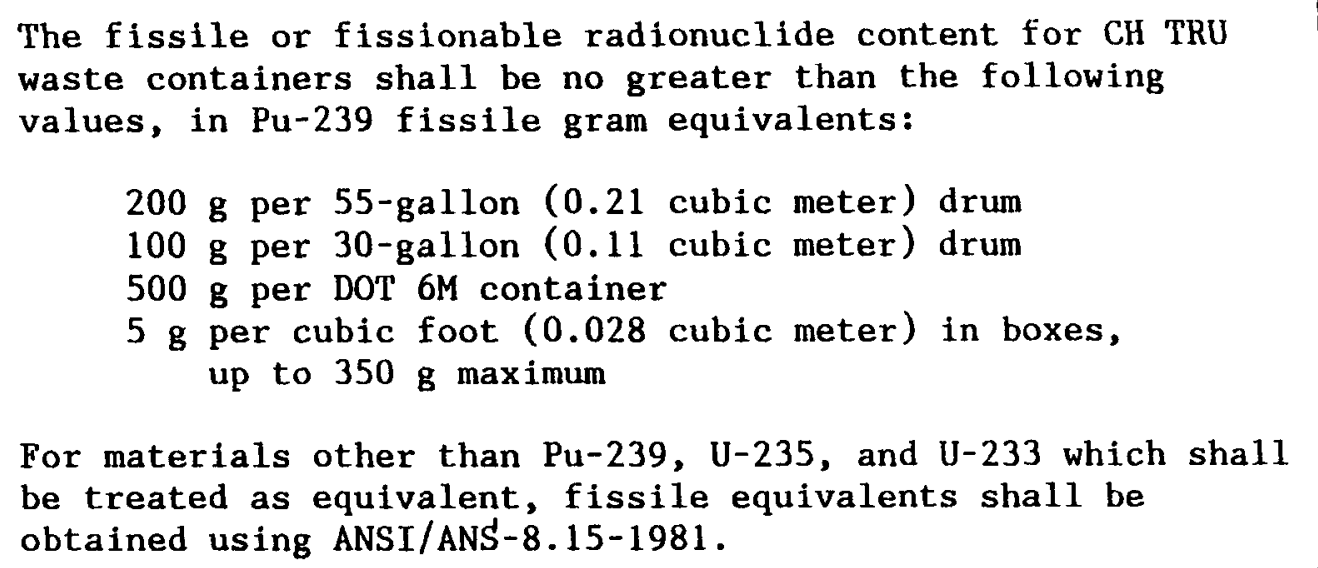 & $\begin{array}{l}\text { The fissile or fissionable radionuclide } \\
\text { content of RH TRU waste shall not exceed } \\
600 \mathrm{~g} \text { total (in Pu-239 fissile gram } \\
\text { equivalents). } \\
\text { For materials other than } \mathrm{Pu}-239 \text {, U- } 235 \text {, and } \\
\mathrm{U}-233 \text { which shall be treated as equivalent, } \\
\text { fissile equivalents shall be obtained using } \\
\text { ANSI/ANS-8.15-1981. }\end{array}$ \\
\hline $\begin{array}{l}\text { PU-239 EQUIV. } \\
\text { ACTIVITY }\end{array}$ & $\begin{array}{l}\text { Waste packages shall not exceed } 1000 \mathrm{Ci} \text { of } \mathrm{Pu}-239 \text { equivalent } \\
\text { activity (PE-Ci). }\end{array}$ & Same as contact-handled. \\
\hline $\begin{array}{l}\text { SURFACE } \\
\text { DOSE } \\
\text { RATE }\end{array}$ & $\begin{array}{l}\text { Waste packages shall have a maximum surface dose rate at any } \\
\text { point no greater than } 200 \mathrm{mRem} / \mathrm{hr} \text {. Neutron contributions of } \\
\text { greater than } 20 \mathrm{mRem} / \mathrm{hr} \text { to the total package dose rate shall } \\
\text { be reported separately in the data package. }\end{array}$ & $\begin{array}{l}\text { Remote-handled TRU waste packages shall have } \\
\text { a surface dose rate at any point no greater } \\
\text { than } 1000 \mathrm{Rem} / \mathrm{hr} \text {. Neutron contributions are } \\
\text { limited to } 270 \mathrm{mRem} / \mathrm{hr} \text {. Neutron contribution } \\
\text { of greater than } 20 \mathrm{mRem} / \mathrm{hr} \text { to the total } \\
\text { package dose rate shall be reported in } \\
\text { the data package. WIPP prior approval is } \\
\text { required before RH TRU canisters with a dose } \\
\text { rate in excess of } 100 \mathrm{Rem} / \mathrm{hr} \text { but less than } \\
1000 \mathrm{Rem} / \mathrm{hr} \text { may be shipped to the WIPP. }\end{array}$ \\
\hline $\begin{array}{l}\text { SURFACE } \\
\text { CONTAMINATION }\end{array}$ & $\begin{array}{l}\text { Contact-handled TRU waste packages or package assemblies shall } \\
\text { have a removable surface contamination no greater than } 50 \\
\text { picocuries per } 100 \text { square centimeters for alpha-emitting } \\
\text { radionuclides and } 450 \text { picocuries per } 100 \text { square centimeters } \\
\text { for beta-gamma-emitting radionuclides. }\end{array}$ & Same as contact-handled. \\
\hline
\end{tabular}




\begin{tabular}{|c|c|c|}
\hline WAC & CONTACT-HANDLED & REMOTE-HANDLED \\
\hline $\begin{array}{l}\text { THERMAL } \\
\text { POWER }\end{array}$ & $\begin{array}{l}\text { Individual } \mathrm{CH} \text { TRU waste packages in which the average } \\
\text { thermal power density exceeds } 0.1 \text { watt/cubic foot } \\
\text { ( } 3.5 \mathrm{~W} / \text { cubic meter) shall have the thermal power recorded } \\
\text { in the data package. }\end{array}$ & $\begin{array}{l}\text { The thermal power generated by waste materials } \\
\text { in any RH TRU waste package shall not exceed } \\
300 \text { watts. The thermal power shall be } \\
\text { recorded in the data package. }\end{array}$ \\
\hline $\begin{array}{c}\text { GAS } \\
\text { GENERATION }\end{array}$ & $\begin{array}{l}\text { Waste packages containing waste forms known or suspected of } \\
\text { gas generation, such that a combination of overpressure and } \\
\text { explosive mixtures might damage the container in the long } \\
\text { term, shall be provided with an appropriate method of pressure } \\
\text { relief. Any liner other than plastic bagging shall be pro- } \\
\text { vided with positive gas communication to the outer container. } \\
\text { Each TRU waste shipper shall provide the following data for } \\
\text { each waste package: } \\
\quad \text { - Total activity (alpha Ci) } \\
\quad \text { - Waste form description (from Certification Plan) } \\
\quad \text { - Mass and volume percent of organic content } \\
\text { For purposes of transportation and emplacement (short term), } \\
\text { there will be no mixture of gases or vapors in any package } \\
\text { which could, through any credible spontaneous increase of } \\
\text { heat or pressure, or through an explosion, significantly } \\
\text { reduce the effectiveness of the packaging. }\end{array}$ & All RH TRU waste canisters shall be vented. \\
\hline LABELING & $\begin{array}{l}\text { In addition to DOT labeling requirements, each waste package } \\
\text { shall be uniquely identified by means of a label permanently } \\
\text { attached in a conspicuous location. The package identifi- } \\
\text { cation number (to be standardized) shall be in medium to low } \\
\text { density Code } 39 \text { barcode symbology per MIL-STD-1189 in char- } \\
\text { acters at least } 1 \text { inch high, and alphanumeric characters at } \\
\text { least } 1 / 2 \text { inch high. } \\
\text { The label must be reasonably expected to remain legible and } \\
\text { affixed to the container for a period of } 10 \text { years under } \\
\text { anticipated conditions of interim storage before shipment to } \\
\text { the WIPP and emplacement underground. }\end{array}$ & $\begin{array}{l}\text { Each waste package shall be uniquely identi- } \\
\text { fied by means of an identification number } \\
\text { permanently attached to the container in a } \\
\text { conspicuous location using characters at } \\
\text { least } 2 \text { inches high. } \\
\text { The label must be reasonably expected to } \\
\text { remain legible and affixed to the container } \\
\text { for a period of } 10 \text { years under anticipated } \\
\text { conditions of interim storage before shipment } \\
\text { to the WIPP and emplacement underground. }\end{array}$ \\
\hline
\end{tabular}




\begin{tabular}{|c|c|c|}
\hline WAC & CONTACT-HANDLED & REMOTE-HANDLED \\
\hline $\begin{array}{c}\text { DATA } \\
\text { PACKAGE }\end{array}$ & $\begin{array}{l}\text { There shall be transmitted to the WIPP operator in advance of } \\
\text { shipment, a data package/certification attesting to the fact } \\
\text { that the waste package meets the requirements of these } \\
\text { criteria. This data package/certification shall be based upon } \\
\text { a quality assurance program subject to audit and verification } \\
\text { and shall provide information on the items specified below: } \\
\text { - Package identification number } \\
\text { - Package assembly identification number (if applicable) } \\
\text { - Date of waste package certification } \\
\text { - WAC exception number (if applicable) } \\
\text { - Waste generation site } \\
\text { - Date of packaging (closure date) } \\
\text { - Maximum surface dose rate in mRem/hr and specific neutron } \\
\text { dose rate if greater than } 20 \text { mRem/hr. } \\
\text { - Weight (in kg) } \\
\text { - Container type } \\
\text { - Physical description of waste form (content code) } \\
\text { - Assay information, including PE-Ci, alpha Ci, and Pu-239 } \\
\text { fissile gram equivalent content } \\
\text { - Radionuclide information including radionuclide symbol, } \\
\text { quantity, and measure (in grams or Curies) }\end{array}$ & $\begin{array}{l}\text { The data package requirements for RH TRU } \\
\text { waste shipments are the same as those for } \mathrm{CH} \\
\text { TRU waste shipments with the following } \\
\text { exceptions: } \\
\text { - The package assembly identification } \\
\text { requirement does not apply to RH TRU } \\
\text { waste shipments } \\
\text { - The cask number shall be used in place } \\
\text { of the TRUPACT number } \\
\text { - No organic materials information needed }\end{array}$ \\
\hline
\end{tabular}




\begin{tabular}{|c|c|c|}
\hline WAC & CONTACT-HANDLED & REMOTE-HANDLED \\
\hline $\begin{array}{l}\text { DATA } \\
\text { PACKAGE } \\
\text { (continued) }\end{array}$ & $\begin{array}{l}\text { - Radioactive mixed waste (identity and quantity of } \\
\text { hazardous waste characteristic(s)) } \\
\text { - Weight and volume percent of organic materials content } \\
\text { - Measured or calculated thermal power (if over } 0.1 \text { watt/ } \\
\text { cubic foot) } \\
\text { - Shipment number } \\
\text { - Date of shipment } \\
\text { - Vehicle type } \\
\text { - TRUPACT number(s) } \\
\text { - Other information considered significant by the shipper } \\
\text { - Name of certifying official who certified the waste package } \\
\text { - Name of person who certifies that the shipment meets the } \\
\text { TRUPACT Authorized Payload Compliance Plan } \\
\text { A hard copy of the signed and dated Certification statement, } \\
\text { certifying that the waste content and packaging are in accord } \\
\text { with the WIPP WAC and that the waste is unclassified, shall } \\
\text { be maintained on file at each site for WACCC audits. }\end{array}$ & \\
\hline $\begin{array}{c}\text { RH TRU } \\
\text { ACTIVITY } \\
\text { IONCENTRATION }\end{array}$ & No criterion. & $\begin{array}{l}\text { The maximum activity concentration for a } \\
\text { remote-handled TRU waste package shall not } \\
\text { exceed } 23 \text { Curies/liter. The concentration } \\
\text { may be averaged over the waste container. }\end{array}$ \\
\hline
\end{tabular}




\subsection{CRITERTON: WASTE CONTAINERS}

\subsubsection{Contact-Handled Waste}

Waste containers for emplacement at the WIPP shall be noncombustible and meet all the applicable requirements of 49 CFR 173.412 for Type A packaging. Waste containers of various sizes shown to meet DOT Type A requirements by the methods detailed in MIM 3245 (Reference 22) are acceptable to WIPP. In addition, they shall have a design life of at least 20 years from the date of certification.

Any waste containers that appear to be bulged or otherwise damaged shall be repackaged or overpacked in a container meeting the above requirements.

\subsubsection{Remote-Handled Waste}

Remote-handled TRU waste containers shall be noncombustible and meet, as a minimum, the structural requirements and design conditions for Type A packaging contained in 49 CFR 173.412. Due to the special characteristic and application of the RH TRU canister, the compression test requirement of 49 CFR 173.465 (d) is not applicable. In addition, all $\mathrm{RH}$ waste containers shall be certified to a WIPP-approved specification to have a design life of at least 20 years from the date of certification.

\subsubsection{Technical Justification}

Past practice in TRU waste disposal has been to package TRU waste materials in waste containers ("packagings" as used in DOT regulations) that meet the currently applicable requirements of the DoT for Type A radicactive material packaging as specified in 49 CFR 178.350. These containers, such as the Spec. $17 \mathrm{C}$ and $17 \mathrm{H}$ 55-gallon drums and the Spec. 7A Rocky Flats boxes, meet certain minimm requirements for durability and are capable of passing prescribed tests to ensure their suitability for transport. Waste containers 
shown to meet DOT Type A requirements by the methods detailed in MIM 3245 are also acceptable to WIPP.

The CH waste handling system at the WIPP is not appreciably different in operation from past practices in $\mathrm{CH}$ waste handling and will not expose waste packages to any additional handling stresses. However, the WIPP does impose a 15-year retrievability period on TRU waste while maintaining waste container integrity, which may affect use of single-trip containers such as the $17 \mathrm{C}$ and 17H drums. In addition, the combustibility studies (Reference 5) have shown that the fiberglass reinforced polyester (FRP) coated plywood boxes are unacceptable without an overpacking steel container.

Remote-handled waste will be handled only by remote means in the WIPP hot cell and facility cask. This will minimize personnel exposure to potential accidents and will permit on site handling of RH waste in Type A containers. Remote-handled waste packages emplaced in the WIPP must also be retrievable for a period of 15 years after emplacement and those containers must be fitted with filtered vents. In addition, RH containers must also be compatible with the remote handling equipment used at the WIPP and must not have any protrusions that could interfere with insertion and removal from casks, racks, storage sleeves, etc.

Since RH canisters for the WIPP will be of special design, certification will be required that RH containers have been designed, fabricated and tested to a specification acceptable to the WIPP Project.

Since much of the waste will be packaged and put in interim storage several years prior to being shipped to WIPP, 20 years has been established as the design life for the combination of the waste container and the protective coating (e.g., paint). It should not be interpreted that the paint itself must have a 20-year Iifetime without defect. 


\subsection{CRITERION: WASIE PACKAGE SIZE}

\subsubsection{Contact-Handled Waste}

$\mathrm{CH}$ TRU waste packages or package assemblies shall not exceed $12 \times 8 \times 8.5$ feet $(3.7 \times 2.4 \times 2.6 \mathrm{~m})$ in overall $\mathrm{L} \times \mathrm{W} \times \mathrm{H}$ dimensions.

\subsubsection{Remote-Handled Waste}

RH TRU waste packages shall be no larger than a nominal 26 inches $(0.66 \mathrm{~m})$ in diameter with a maximm length of 10 feet, 1 inch $(3.1 \mathrm{~m})$ including the pintle.

\subsubsection{Technical Justification}

The size of $\mathrm{CH}$ waste packages in the WIPP is Iimited by access to the waste hoist and the size of the waste hoist cage. The waste hoist cage has a floor that is capable of accepting a package that is $8 \times 12$ feet in width and length respectively, with a clearance of 3 inches for loading and unloading. The hoist cage access door from the $\mathrm{CH}$ handling area has a door height of 12 feet. CH waste packages are loaded on the hoist cage with a cage loading car. Allowing for cage loading car clearance from the floor, this leaves approximately 8.5 feet and provides a nominal 3-inch clearance for loading and unloading the hoist cage.

The RH waste hot cell handling equipment is designed to handle an overpacked RH TRU waste container with overall dimensions of 28 inches in diameter by 11 feet, 1 inch in length. The overpack will be able to accept an RH TRU waste package with 26-inch diameter by 10-foot, 1-inch length dimensions, including the lifting pintle. The nominal diameter of the RH TRU waste package is important, since in the WIPP facility the waste package is moved from the hot cell to its emplaced location in a facility transfer cask. Throughput and canister handling requirements indicate that for the WIPP RH facility to meet the cubic foot throughput requirements $\left(10,000 \mathrm{ft}^{3} / \mathrm{yr}\right.$, Reference 3) all canisters handled must be near the largest allowable length of 
10 feet, 1 inch. There is no technical problem in handling waste packages of shorter length, but shorter packages would be less economical and would reduce facility throughput capabilities. Therefore, RH TRU waste must be packaged in a standard WIPP container which must approach the 26-inch diameter by 10-foot, 1-inch maximum size in order to meet WIPP throughput goals.

\subsection{CRTIERION: WASTE PACKAGE HANDITNG}

\subsubsection{Contact-Handled Waste}

All waste packages shall be provided with cleats, offsets, chimes, or skids for handling by means of fork trucks, cranes, or similar handling devices. Lifting rings and other auxiliary lifting devices on the packages, if provided, shall be recessed, offset, or hinged in a manner which does not inhibit stacking the packages.

\subsubsection{Remote-Handled Waste}

RH IRU waste packages shall be equipped with an axial lifting pintle of a design acceptable to the WIPP. The packages shall have no other lifting devices.

\subsubsection{Technical Justification}

CH waste has been historically packaged mostly in 55-gallon drums or in boxes and bins which are routinely handled with standard fork-type trucks or fork trucks with drum-handling attachments. When loading and unloading TRUPACIS, the packages will be handled with overhead cranes.

$\mathrm{RH}$ waste is less well characterized as far as normal packaging and handling practices. Most RH waste appears to be stored in 30- and 55-gallon drums, although there are great variations in other packages used for the remainder. Many of the drums have been overpacked with concrete containers to reduce the surface dose rate to allow contact handling of the concrete-encased package in temporary storage facilities. 
The WIPP CH waste handling system is designed to use slip sheets, standard fork trucks or fork trucks with drum handling or special seven-pack handling attachments as the basic prime movers for use both within the waste handling building and in the underground emplacement areas. WIPP's use of slip sheets will not affect the handling methods used at various waste generating sites around the US.

The WIPP RH hot cell facility will only handle standardized waste containers and will handle them only in a vertical orientation. Each container must have attached to it an axial lifting pintle that will engage the lifting devices in the $\mathrm{RH}$ hot cell and facility transfer cask. This pintle is described in the RH canister user's manual (Reference 24). All RH waste packages must be cylindrical, smooth-sided, and have no flanges or protrusions that would hinder insertion or removal from casks, storage racks, sleeves, etc. The WIPP RH handling requirements will require waste generating sites to fabricate and use standard-sized waste containers with axial handling penults that are compatible with WIPP RH handling equipment. 
4.0 WASTE FORM REQUIREMENTS

\subsection{CRITERION: TMMOBIIIZATION}

\subsubsection{Contact-Handled Waste}

Powders, ashes, and similar particulate waste materials shall be immobilized if more than 1 weight percent of the waste matrix in each package is in the form of particles below 10 microns in diameter, or if more than 15 weight percent is in the form of particles below 200 microns in diameter.

\subsubsection{Remote-Handled Waste}

Powders, ashes, and similar particulate waste materials shall be immobilized if more than 1 weight percent of the waste matrix in each package is in the form of particles below 10 microns in diameter or if more than 15 weight percent is in the form of particles below 200 microns in diameter.

\subsubsection{Technical Justification}

\subsubsection{Mobility Enhancement Concern (Reference 5)}

The WIPP experimental program has emphasized waste/rock interactions and the subsequent interaction of the released radionuclides with the local geologic enviroment. Studies have been devoted to the identification of concerns that would lead to restrictions on waste form. The requirement for leachability criteria has been considered in view of the conclusions resulting from bounding consequence assessment calculations. Waste form and container degradation have been shown to produce chemical species whose interactions with the waste can reduce radionuclide sorption on rock in or near the storage facility. consequently, these degradation reactions have been studied to identify potential complexing agents, particularly organics, which can enhance radionuclide mobility. Observations from these studies have been compared with data for sorption in the WIPP enviromment and with calculations that predict the consequences of radionuclide release scenarios. 
A by-product of these studies has been the identification and testing of "getter" materials that are strong sorbers of the radionuclides, particularly the actinides in the waste and can serve as barriers to water movement toward the waste containers. While there is no present justification for including getters as an integral part of individual waste packages, some materials such as bentonite clays show great promise as an additional element of the "multiple barrier" concept. The most effective use of getters may be as a backfill material or a water absorbent.

The principal isolation barrier in the WIPP is the local host rock, which inhibits the intrusion of fluid and the subsequent escape of radionuclides. This isolation is provided by the large thickness of the low-permeability salt at the repository horizon, by a very favorable (regional) hydrology near the site, and by the sorptive properties of the adjacent (or bounding) rock salt and other rock strata. Calculations which assess the potential consequences of assumed radioactive materials release scenarios have been performed using empirical data for both the flow system and the sorptive capacity of the rock. Further, very conservative assumptions that the waste dissolves instantly when contacted by water, and that the resulting "solution" moves with the same velocity as water through the host rock, were also employed.

Studies addressing the various aspects of waste-form stability and radionuclide mobility have led to the following conclusions:

1. The consequence assessments for the WIPP have identified that brine intrusion into the geologic containment will have negligible risk to the public (Reference 6). These studies assumed waste dissolution rates equivalent to that of the salt itself (and orders of magnitude in excess of those found experimentally in proposed developmental waste forms, or in currently existing TRU waste which contains actinides in forms of extremely low solubility). Leaching studies on existing waste forms would be not only experimentally difficult but very likely inconclusive because of the very large variety and diversity of waste forms. Evaluation of data collected through February 1988, shows the amount of brine seepage to be relatively small and not impactive to long-term isolation of the 
waste. Proper packaging can obviate the concern for small quantities of liquids in containers which might accelerate the corrosion process during the retrieval period.

2. Complexing agents have been found that can substantially decrease the sorptive capacity of the host rock for radiomuclides such as Pu. However, analyses have demonstrated the insensitivity of nuclide release rates at the biosphere outlet to large variations in the assumed adsorption coefficients (Reference 8). This is due to both the long travel time for natural water flow between the WIPP site and the accessible envirorment and the long half-lives of the muclides involved.

\subsubsection{Dispersibility and Inhalation concern}

In addition to long-term concerns about in-situ immobilization, there exists an immediate hazard to the general public and WIPP operating personnel if powdered or potentially airborne TRU waste forms are routinely handled. A breach of a waste container holding a finely divided waste form could cause widespread contamination (which is another kind of radionuclide mobility). Studies have shown that particles less than 10 microns in diameter pose the greatest hazard of being inhaled and retained in human lungs (Reference 9). Therefore, it is desirable to minimize these respirable fines in any waste package.

Since it cannot be guaranteed that there are absolutely no respirable particles in a waste package, the criterion effectively-limits the quantities of respirable dust to a restrictive but achievable level of 1 percent by weight.

Further analysis for the WIPP Safety Analysis Report supports the 1 percent criterion by showing that dose commitments to WIPP operating personnel are acceptable, under accident conditions, if the 1 percent criterion is used.

Particles under 200 microns in diameter (fine sand size) are readily dispersible and would contaminate the inmediate vicinity in the event of a 
spill. These do not create a situation as hazardous as respirable particles, but decontamination and clean up do increase overall personnel exposures. Fifteen percent by weight was selected as an upper limit to minimize the effect of a spill involving particles of this size range.

\subsection{CRITERTON: LIQUTD WASTES}

\subsubsection{Contact-Handled Waste}

TRU waste shall not be in free-liquid form. Minor liquid residues remaining in well-drained bottles, cans, and other containers are acceptable.

\subsubsection{Remote-Handled Waste}

TRU waste shall not be in free-liquid form. Minor liquid residues remaining in well-drained bottles, cans, and other containers are acceptable.

\subsubsection{Technical Justification}

The prohibition against the presence of free liquids is applied to TRU waste sludges (some initially containing up to 60 percent water) as well as other liquids. The presence of free liquids would provide a significant potential for releasing contaminated liquids if containers failed during receipt, handling, or emplacement operations. Although personnel exposure curing such an accident would typically tend to be small, decontamination activities in below-ground facilities in the salt could be difficult. Eliminating free liquids recuces the probability and potential magnitude of contamination events.

Consequences of liquids during the retrieval period are related to container leakage. Liquids could possibly accelerate container corrosion rates from the inside causing a release of liquid to the salt storage medium. Interaction of the liquids, especially water, with the salt could result in brine formation. Depending on the quantities of liquid involved, brine solution could spread to adjacent containers, perhaps jeopardizing their structural 
integrity. Retrieval, if necessary, would be adversely affected if several containers' integrities were at risk.

Brine formation or other interactions involving liquids and the salt medium have been evaluated for other possible hazards, such as strong acids, chlorine gas, etc., with the conclusion that toxic substances would not be formed.

It should be noted that processes are available and planned for dewatering and immobilizing sludges at several DOE facilities, such that liquid contents are reduced to as little as 10 to 15 weight percent. Further, authorization to ship fissile materials in liquid form is most difficult to obtain, and shipments of liquid wastes are not included in the current DOE transportation plan. Based on the above, the quantities of free liquid shipped to WIPP are restricted.

\subsection{CRITERTON: PYROPHORIC MATERIALS}

\subsubsection{Contact-Handled Waste}

Pyrophoric materials, other than radionuclides, shall be rendered safe by mixing with chemically stable materials (e.g., concrete, glass, etc.) or processed to remove their hazardous properties. No more than 1 percent by weight of the waste in each package may be pyrophoric forms of radionuclides, and these shall be generally dispersed in the waste.

\subsubsection{Remote-Handled Waste}

Pyrophoric materials, other than radionuclides, shall be rendered safe by mixing with chemically stable materials (e.g., concrete, glass, etc.) or processed to remove their hazardous properties. No more than 1 percent by weight of the waste in each package may be pyrophoric forms of radionuclides, and these shall be generally dispersed in the waste. 


\subsubsection{Technical Justification}

Pyrophoric materials which could ignite spontaneously under conditions of transportation, handling, or emplacement also present a special hazard. A comprehensive listing of these materials is presented in 49 CFR 173, subparts D and $\mathrm{E}$.

Presently, many waste generating sites routinely dispose of small quantities of materials of a pyrophoric nature (and form) in TRU waste packages. commonly used materials that would fall under the pyrophoric classification, in addition to the radionuclide materials themselves, are titanium, magnesium, and zirconium metals and alloys, white and yellow phosphorous, and alkali metals. Uranium and plutonium metals are considered pyrophoric under many conditions. Packaging, transportation, handling, and emplacement of uncontrolled quantities of these potentially pyrophoric materials could result in fires, personnel injury, and contamination spread via products of combustion. Even though these materials are packaged in accordance with DOT regulations to preclude ignition and are not expected to ignite under the normal enviromental conditions encountered during transportation, handling, and emplacement (Reference 7), the instability of these materials reasonably justifies either limiting their quantity and requiring their dispersion (to minimize their pyrophoric nature) in any single TRU waste package or requiring their processing to a nonpyrophoric form.

The waste forms being procuced at the waste generating facilities include small quantities of transuranic metals in pyrophoric form (i.e., primarily small dustlike particles in the form of TRU contamination). Fortunately, these pyrophoric forms of the transuranic metals are relatively uniformly dispersed throughout the waste packages, thereby rendering the material safe since it is not concentrated in sufficient quantities to become hazardous. The waste forms being produced at the waste generating facilities also include certain quantities of nonradionuclide pyrophoric materials such as magnesium and zirconium metals and alloys, as well as others.

Studies at Rocky Flats (Reference 10) have shown that small quantities of pyrophoric plutonium can be accommodated in other nonpyrophoric materials without an unacceptable hazard. A 1-percent limit has been established in the 
criteria for the WIPP as an acceptable level of pyrophoric material in a transuranic waste package. This allows a limited quantity of nonfissionable waste (which varies according to package weight) to be contained in each package beyond the 100-, 200-, and 350-gram limits for fissile radionuclides in the various-sized waste containers. The 1 percent is used instead of 3 percent since TRU waste forms are not as uniform or homogeneous as the materials in the Rocky Flats study, and there is no guarantee of uniform dispersal of pyrophorics in TRU waste.

The waste acceptance criteria for pyrophoric materials or materials which in combination are pyrophoric permit nonradioactive, TRU-contaminated pyrophoric materials in any quantity to be emplaced in the WIPP if such materials have been rendered safe by uniformly mixing them with chemically stable materials such as concrete, glass, ceramics, etc., or by processing them to remove the hazardous pyrophoric properties.

These requirements are imposed in order to restrict the quantity of pyrophoric materials emplaced at the WIPP in any single waste package and thereby recuce any potential hazard. The pyrophoric forms of the radionuclides cannot be excluded from the waste packages emplaced at the WIPP, since they can be construed to be pyrophoric under almost any condition. However, other pyrophoric materials must be restricted to acceptable levels to avoid the possibility of using the WIPP as a hazardous chemical disposal facility.

\subsection{CRITERION: EXPLOSIVES AND COMPRESSED GASES}

\subsubsection{Contact-Handled Waste}

TRU waste shall contain no explosives or compressed gases as defined by 49 CFR 173, subparts C and G.

\subsubsection{Remote-Handled Waste}

TRU waste shall contain no explosives or compressed gases as defined by 49 CFR 173, subparts C and G. 


\subsubsection{Technical Justification}

Certain materials could present an extreme hazard if they are contained in TRU waste packages. Explosive materials and compressed gases, by their nature, not only present a hazard to operating personnel during shipment and handling, but also increase the chance of failure of individual waste packages containing such materials curing storage and provide an improbable but possible source for a propagating failure of waste packages in a storage array. Therefore, a criterion to prohibit these materials in the WIPP has been established.

The WIPP is not designed to handle or store explosive materials or compressed gases, nor are TRU-contaminated explosive materials or compressed gases expected to be generated in any appreciable quantities at the waste generating sites. Accordingly, neither explosive materials nor compressed gases will be accepted for emplacement at the WIPP.

\subsection{CRITERION: RADIOACITVE MIXED WASTES}

\subsubsection{Contact-Handled Waste}

TRU wastes shall contain no hazardous wastes unless they exist as co-contaminants with transuranics. Waste packages containing hazardous materials shall be identified with the appropriate DOT label. TRU-contaminated corrosive materials shall be neutralized, rendered noncorrosive, or packaged in a manner to ensure container adequacy through the design lifetime. Hazardous materials to be reported are listed in 40 CFR 261, subparts C and D.

\subsubsection{Remote-Handled Waste}

TRU wastes shall contain no hazardous wastes unless they exist as co-contaminants with transuranics. TRU-contaminated corrosive materials shall be neutralized, rendered noncomrosive, or packaged in a manner to ensure container adequacy through the design lifetime. Hazardous materials to be reported are listed in 40 CFR 261, subparts C and D. 


\subsubsection{Technical Justification}

The WIPP is not intended to be a hazardous waste disposal facility, and there are no plans to ship highly toxic substances as such to the WIPP. However, some of the IRU waste to be shipped to the WIPP might also fall within the accepted definition of hazardous waste. Waste which falls within both TRU and hazardous waste definitions is called "Radioactive Mixed Waste," defined and addressed in DOE Order 5480.2, "Hazardous and Radicactive Mixed Waste Management," specifically, DOE order 5480.2, Chapter II, paragraph 2(a) states:

"For high level and transuranic mixed waste, DOE 5820.2 radiological control requirements for handling, packaging, transportation, storage, disposal, and monitoring shall be applied. The field office manager shall verify that these requirements provide adequate protection for the public and the enviroment from potential hazards which may derive from hazardous characteristics other than radioactivity, and shall impose any additional requirements that will be necessary to achieve such protection."

The DOE has decided that mixed waste shall be handled in accordance with the Resource Conservation and Recovery Act (RCRA) under regulations written by the Enviromental Protection Agency (EPA).

Mixed waste for shipment to the WIPP must first meet the definition for TRU waste. Nonradioactive hazardous waste, low-level mixed, or high-level mixed wastes are not to be shipped to WIPP. Further, the hazardous waste constituents (components which make waste hazardous) must exist as co-contaminants due to generator site work activities. Adding hazardous wastes to TRU waste streams for ease for hazardous waste disposal is not allowed. Radioactive mixed wastes are a health and safety concern to the WIPP, and their presence requires a determination that plans for packaging, handling, shipping, emplacement, retrieval, and long term storage at the WIPP include adequate health and safety considerations.

The four characteristics which make waste hazardous are: 


\section{EP Toxicity}

The primary health and safety concerns relative to public and worker safety involve human exposure to either respirable airborne or drinking water concentrations of toxic materials. The transuranic (radioactive) constituents in wastes contribute the most substantial toxicity hazard. Therefore, adequate considerations of the hazards inherent in shipping, handling, and disposal operations at the WIPP for the TRU radicactive components will, by definition, provide adequate protection from hazards to the presence of other substances identified in the EP Toxicity list.

Neither the regulations governing hazardous waste disposal nor the WIPP-WAC allow disposal of waste in liquid form. Hazardous waste in solid form is normally disposed of by shallow land-burial techniques. These techniques are judged adequate to protect the health of the public from the basic toxicity characteristic. Because of the TRU radioactive materials component of the waste for the WIPP, disposal is in a dry salt formation about 2100 feet below the surface. The contaiment provided by the salt formation is orders of magnitude greater than shallow land burial requirements for hazardous wastes.

WIPP criteria require all waste to be packaged in approved DOT Type A containers for disposal. For shipment to WIPP, the Type A containers will be overpacked in a DOT Type B equivalent container. Due to the rigorous requirements for packaging, labeling, placarding, transportation, storing and disposing of TRU radicactive waste under DOE orders and related DOT regulations, these requirements are equivalent to or more stringent than regulations applying to other types of hazardous or toxic substances. In short, health and safety protection required by these criteria, because of the presence of the toxic TRU component, provide more than adequate safety for handling and disposing of the radioactive mixed wastes. 


\section{Corrosivity}

Corrosives possibly present problems to the WIPP from a safety handling standpoint and from a retrievability standpoint (container degradation could adversely affect retrievability). Corrosives, however, are easily neutralized or reacted chemically to procuce a noncorrosive form. Further, use of a corrosive-resistent inner liner (a 90-mil rigid polyethylene liner, for example) with the standard Type A container is adequate to ensure that the waste package will remain intact for the retrieval period. Therefore, WIPP criteria adequately address corrosivity.

\section{Reactivity}

It is possible that small quantities of TRU waste might contain reactive materials (magnesium, sodium, potassium, etc.) distributed on radioactively contaminated components as a thin film, or present as residue inside cracks, crevices, etc. When properly packaged, these materials present little or no hazard. Since reactive materials are hazardous when they come in contact with water, handling and storage at the WIPP might present safety problems (in the event of a fire fought with water). Therefore, the WIPP requires that reactive materials be specifically identified by the appropriate DOT label on the container and in the data package. Liquid waste forms are not allowed in the WIPP wastes and storage is in dry, bedded salt.

\section{Ignitability}

Ignitable (pyrophoric) materials are precluded by the WIPP criteria. Therefore, the protection afforded by adherence to the WIPP criteria and the DOT regulations for packaging has been shown to be more than adequate for the major health hazards from hazardous wastes, namely toxicity, corrosivity ignitability, and reactivity. The requirements 
of DOE Order 5480.2, Chapter II, paragraph 2 (a) are met by adherence to the WIPP-WAC.

\subsection{CRITERTON: SPECIFIC ACIIVITY OF WASTE}

\subsubsection{Contact-Handled Waste}

For purposes of TRU waste certification, the $100 \mathrm{nCi} / \mathrm{g}$ TRU waste limit shall be interpreted as $100 \mathrm{nCi}$ per gram of waste matrix. The weight of added external shielding and the containers (including any rigid liners) should be subtracted prior to performing the $\mathrm{nCi} / \mathrm{g}$ calculation.

\subsubsection{Remote-Handled Waste}

For purposes of TRU waste certification, the $100 \mathrm{nCi} / \mathrm{g}$ TRU waste 1 imit shall be interpreted as $100 \mathrm{nCi}$ per gram of waste matrix. The weight of added external shielding and the containers (including any rigid liners) should be subtracted prior to performing the $\mathrm{nCi} / \mathrm{g}$ calculation.

\subsubsection{Technical Justification}

DOE order 5820.2A, Chapter II.3.a.(2), (Reference 23) states:

"The lower concentration limit for transuranic waste (>100 nCi/g of waste) shall apply to the contents of any single waste package at the time of assay. The mass of the waste container including shielding shall not be used in calculating specific activity of the waste."

DOE Order 5820.2A also defines a waste container as:

"A receptacle for waste, including any liner or shielding material that is intended to accompany the waste in disposal."

The WAC for specific activity has been developed by using the above definitions. 


\subsection{DISCUSSION: COMBUSTIBIITIY}

There is no need to limit the combustibles present in the waste provided that the waste containers are noncombustible. consequently, there is no criterion for combustibility in $\mathrm{CH}$ or $\mathrm{RH}$ TRU waste.

Most of the existing $C H$ TRU waste is stored in DOT $17 \mathrm{C}$ or $17 \mathrm{H} 55$-gallon drums, rectangular metal boxes or in DOT 7A FRP-coated plywood boxes. Since the packaged waste is known to contain substantial amounts of organic material, the waste itself is considered to be combustible. Examination of the combustibility issue focused on the containers in which the waste is to be received at the WIPP. Specifically, the capability of these containers to function as "fire barriers" intended to prevent involvement of the contained waste in postulated fire scenarios was examined.

Secondary container capability issues were that: a) containers themselves were not to be combustible, adding fuel to the fire, b) containers should not act as a means of fire propagation, and c) containers should not present problems such as stack instability or explosion hazards that could produce high-speed missiles. These items were the subject of fire studies conducted by Sandia National Laboratories.

The tests focused on $\mathrm{CH}$ waste because, although RH TRU waste exists in essentially the same variety of forms as does CH TRU waste, it is always packaged in metallic containers and is always isolated from possible exposure to fires by a shielding cask or, after emplacement, by salt. There is, therefore, no credible mechanism by which RH TRU waste could become involved in a WIPP fire.

Because experimental evidence (Reference 7) supplemented by operational history supports the conclusion that there is minimal risk of sustained combustion of packaged TRU waste due to spontaneous intermal ignition, the fire hazard to the WIPP facility is primarily limited to exposure of waste packages to external fires. Concern was therefore focused on those areas of the facility where the $\mathrm{cH}$ waste handling operations are carried out, and the kinds 
of external fires which might occur there, specifically the receiving and staging areas at the surface and the active storage rooms underground.

In the surface facilities, the appropriate countermeasure for fire hazards is the use of conventional automatic fire detection and suppression systems such as those used in warehouses. Underground, the presence of water and salt together can produce undesirable effects like corrosion and electrical hazards. Further, the storage areas are quite extensive and dispersed, and the point of greatest vulnerability to a fire, the open face of the storage stack, is always moving. Therefore, the problem underground is somewhat different. In order to quantify the fire danger, Sandia conducted fire tests which were designed to simulate severe, but not incredible, fires.

In these tests, FRP-coated plywood boxes, and DOT-17C and DOT-17H-type drums were found to pose possible fire hazards in WIPP accident scenarios, in that they fail (under test conditions) to function as a fire barrier to protect the contained waste. Further, the FRP-coated plywood boxes actually provide fuel for the propagation of a fire, and the protective coating produces a dense toxic smoke. Steel overpacks have been shown in the full-scale fire tests to be effective as a countermeasure to the combustibility of the FRP-coated plywood boxes.

The fire tests also demonstrated that venting drums or steel overpacks is an effective way to relieve internal pressure in the containers, preventing overpressurizing with resultant bulging or exploding. Filters on vents are designed to allow for normal atmospheric pressure relief without release of radioactive material; however, they will probably not prevent drums from rupturing during a fire. The filters would have to have a large flow capacity to handle the rapid outgassing, be able to trap radicactive particles and still not clog due to other particles (smoke), not be consumed by the fire, and not compromise the container integrity for use in shipping.

The totality of the combustibility concerns were studied by the WIPP Project team because of the fire protection design impact. The Sandia fire test data constitute only one aspect of the overall fire protection problem. other aspects are associated with the likelihood of the fire occurrence, its 
potential magnitude, the ability to detect it, and the ability to control it. Further modifications to the containers have been suggested and were considered. The conclusion reached by the WIPP Project staff is that while the fires created in the Sandia tests appear to be quite severe, they are easily prevented and combatted; further the health and safety risks presented by such fires do not require more than overpacking the FRP-coated plywood boxes in appropriate metal containers. The steel overpacks for organic waste containers (FRP-coated plywood boxes or similar containers) have been included as a waste acceptance criterion requirement under the heading of "Waste containers."

Operational techniques and administrative controls will be used to further enhance fire safety in the storage areas. Examples of these are administratively limiting the amount of vehicular traffic and vehicle parking in areas adjacent to amassed waste. These measures, in conjunction with appropriate fire detection and suppression methods for use at the "open" face of the storage stacks, essentially eliminate the storage room fire hazard. 


\subsection{WASTE PACKAGE REQUIREMENTS}

\subsection{CRITERION: WASTE PACKAGE WEIGHT}

\subsubsection{Contact-Handled Waste}

CH TRU waste packages or package assemblies shall weigh no more than 21,000 pounds $(9,550 \mathrm{~kg})$.

\subsubsection{Remote-Handled Waste}

RH TRU waste packages shall weigh no more than 8,000 pounds $(3,630 \mathrm{~kg})$.

\subsubsection{Technical Justification}

The $\mathrm{CH}$ waste handling system of the WIPP is limited in waste package weight handling capability by the capacity of the large fork trucks that will load and unload the $\mathrm{CH}$ waste materials from the waste hoist that transfers waste between the surface and the storage level. These fork trucks are presently specified to have a rated lift capacity of 26,000 pounds $(11,794 \mathrm{~kg})$, and all waste handling operations are to be carried out within the capacity rating.

This rated capacity must include an allowance for pallets and overpacks that may be required, which is estimated to be 5,000 pounds $(2,268 \mathrm{~kg})$. Therefore, a $\mathrm{CH}$ waste package may weigh a maximum of 21,000 pounds $(9,550 \mathrm{~kg})$.

The WIPP has established a RH TRU overpack gross weight limit of 10,000 pounds. It is estimated that a full-size 28 -inch $(0.71 \mathrm{~m})$ by 11-foot, 1-inch $(3.38 \mathrm{~m}) \mathrm{RH}$ TRU overpack may weigh 2,000 pounds $(907 \mathrm{~kg})$, leaving a maximm gross weight of 8,000 pounds $(3630 \mathrm{~kg})$ for a $26-i$ nch $(0.66 \mathrm{~m})$ by 10-foot, 1-inch $(3.07 \mathrm{~m}) \mathrm{RH}$ waste package. 


\subsection{CRITERTON: NUCTEAR CRITICAITTY}

\subsubsection{Contact-Handled Waste}

The fissile or fissionable radionuclide content for $C H$ TRU waste containers shall be no greater than the following values, in Pu-239 fissile gram equivalents:

$200 \mathrm{~g}$ per $55-$ gallon $\left(0.21 \mathrm{~m}^{3}\right)$ drum

$100 \mathrm{~g}$ per 30 -gallon $\left(0.11 \mathrm{~m}^{3}\right)$ drum

$500 \mathrm{~g}$ per DOT $\mathrm{M}$ container

$5 \mathrm{~g}$ per $\mathrm{ft}^{3}\left(0.028 \mathrm{~m}^{3}\right)$ in boxes, up to $350 \mathrm{~g}$ maximum

For materials other than Pu-239, U-235, and U-233 which shall be treated as equivalent, fissile equivalents shall be obtained using ANSI/ANS-8.15-1981.

\subsubsection{Remote-Handled Waste}

The fissile or fissionable radionuclide content of RH TRU waste shall not exceed $600 \mathrm{~g}$ total (in Pu-239 fissile gram equivalents).

For materials other than Pu-239, U-235, and U-233 which shall be treated as equivalent, fissile equivalents shall be obtained using ANSI/ANS-8.15-1981.

\subsubsection{Technical Justification}

Criticality calculations were performed to substantiate the aforementioned limits. The results including sensitivity studies and benchmarking are presented in DOE/WIPP 88-014 "Criticality Safety Analysis for contact Handled Waste at the Waste Isolation Pilot Plant" (Reference 15).

DOE/WIPP 88-014 reports a $K_{\text {eff }}$ (effective multiplication factor) of less than 0.95 for worst case drums (DOT $17 \mathrm{H} 55$-gallon drums without polyethylene 
liners). The drums are filled with graphite and $200 \mathrm{~g}$ of Pu 239 uniformly dispersed throughout the drum.

All calculations and sensitivity studies are based on a $95 \%$ probability at a 95\% confidence limit that the $k_{e f f}$ of the storage array (drums and boxes) will be less than 0.95 . The results of the calculations are further substantiated by the following:

1. The concentration of fissile material in worst-case drums is about $1 \mathrm{~g} / \mathrm{liter}$, whereas the average concentration in DOE (Rocky Flats) waste packages is only about $0.02 \mathrm{~g} /$ /iter for 210-liter drums and $0.002 \mathrm{~g} / \mathrm{liter}$ for $1.2 \times 1.2 \times 2.1-\mathrm{m}$ plywood boxes.

2. No mixture of materials in real TRU waste can be as effective in moderating neutrons as the graphite assumed to be present in the worst-case drums.

3. The inhomogeneities of real waste further reduce $K_{\text {eff }}$.

4. The addition of any material, even a moderator, in the spaces between drums recuces $K_{\text {eff }}$ since calculations are performed with optimm moderation.

Two events that influence criticality in the WIPP are water intrusion and room closure due to creep. As seen above in item 4, water intrusion decreases reactivity. As room closure occurs, $K_{\text {eff }}$ would not exceed 0.95 for the worst case waste composition during array collapse.

For waste forms that may be compacted by treatment (e.g., incineration) before disposal in the WIPP, there would be no significant effect on criticality. Analysis of the 71 categories of Rocky Flats waste indicates that (because of the large fraction of noncombustibles in the waste) the overall increase in fissile nuclide concentration (in a given cubic foot of waste matrix) which results from waste processing is only a factor of 2 to 3 . In any 
case, the fissile inventory of each drum will not be allowed to exceed the existing 200-gram fissile limit regardless of processing and any resulting nuclide concentration. Incineration (or similar processing) and combination of the waste product with glass or concrete, or making the waste into a slag, reduces the reactivity of the stored array from the values calculated in DOE/WIPP 88-014 since the new matrix is a less effective moderator than the graphite matrix previously assumed. Any boron in borosilicate glass or in slag acts as a neutron absorber.

The distinguishing feature of RH TRU waste is its fission product content and not its fissile nuclide content. For the purpose of WIPP safety analyses, the fissile material content of RH TRU waste is limited to $600 \mathrm{~g}$ based on the existing handling and storage configurations within the hot cell, the transfer cell, and underground emplacement. Other loadings may be requested by the shipper for WIPP approval if the request is accompanied by a supplementary criticality analysis. Such criticality analyses should use assumptions sinilar to those specified in Reference 16.

Existing regulations limiting the fissile material content of $C H$ TRU waste packages, which were formulated to ensure criticality safety during transportation and in WIPP storage geometries, are adequate to ensure the criticality safety of packaged TRU waste in the WIPP. 


\subsection{CRITERION: PU-239 EQUTVALENT ACIIVIIY}

\subsubsection{Contact-Handled Waste}

Waste packages shall not exceed $1000 \mathrm{Ci}$ of Pu-239 equivalent activity $(\mathrm{PE}-\mathrm{Ci}$.

\subsubsection{Remote-Handled Waste}

Waste packages shall not exceed $1000 \mathrm{Ci}$ of Pu-239 equivalent activity $(P E-C i)$.

\subsubsection{Technical Justification}

Reference 17 reports $9100 \mathrm{PE}-\mathrm{Ci}$ per $\mathrm{CH}$ waste package and a value in excess of $1 \times 10^{6} \mathrm{PE}-\mathrm{Ci}$ per $\mathrm{RH}$ waste canister as the maximm Pu-239 equivalent activity for individual waste packages. These values ensure that the radiological performance requirements applicable to WIPP are not exceeded.

For conservatism, an operating limit of $1000 \mathrm{PE}-\mathrm{Ci}$ for each waste package is established. If this operating limit of $1000 \mathrm{PE}-\mathrm{Ci}$ significantly impacts a waste generator, a variance may be considered on a case-by-case basis, provided that the parameters of Reference 17 are not exceeded. Other criteria of the WAC (criticality limits) generally limit the activity in the waste containers to significantly less than $1000 \mathrm{PE}-\mathrm{Ci}$.

Pu-239 Equivalent Activity is determined using radionuclide-specific weighting factors. To obtain this correlation, the 50-year effective whole body dose commitment or dose conversion factor (DCF) for a unit intake of each radionuclide with be used. These DCFs have been determined by the methodology described in International commission on Radiological Protection (ICRP) Publications 26 and 30 (References 18 and 19) and are consistent with current Department of Energy guidance (Reference 20). The Pu-239 equivalent activity (AM) can be characterized by: 


$$
A M=\sum_{i=1}^{k} \frac{A_{i}}{W_{i}}
$$

where $k$ is the number of TRU radionuclides, $A_{i}$ is the activity of radionuclide $i$, and $\mathrm{WF}_{i}$ is the $\mathrm{PE}-\mathrm{C} i$ weighting factor for radionuclide $i$.

$\mathrm{WF}_{i}$ is further defined as the ratio:

$$
W F_{i}=\frac{E_{0}}{E_{i}}
$$

Where $E_{O}(r e m / \mu C i)$ is the 50-year effective whole body dose commitment due to the inhalation of Pu-239 particulates with a $1.0 \mathrm{\mu m}$ Activity Median Aerodynamic Diameter (AMAD) and a weekly (W) pulmonary clearance class, and $E_{i}(r e m / \mu \mathrm{Ci})$ is the 50-year effective whole body dose commitment due to the inhalation of radionuclide $i$ particulates with a $1.0 \mu \mathrm{m}$ AMAD and the pulmonary clearance class resulting in the highest 50-year effective whole body dose conmitment.

The value of $E_{0}$ and $E_{i}$ may be obtained from WIPP/DOE-176 (Reference 21). Weighting factors calculated in this manner are presented below for selected radionuclides of interest.

$\begin{array}{lccc}\text { Radionuclide } & \begin{array}{c}\text { Pulmonary } \\ \text { Clearance Class* }\end{array} & \begin{array}{c}\text { Weighting } \\ \text { Factor }\end{array} & \begin{array}{c}1000 \text { Ci Pu-239 } \\ \text { Equivalent (CiE) }\end{array} \\ \text { U-233 } & \text { Y } & & \\ \text { Np-237 } & \text { W } & 4.0 & 4000 \\ \text { Pu-236 } & \text { W } & 1.0 & 1000 \\ \text { Pu-238 } & \text { W } & 3.1 & 3100 \\ \text { Pu-239 } & \text { W } & 1.1 & 1100 \\ \text { Pu-240 } & \text { W } & 1.0 & 1000 \\ \text { Pu-241 } & \text { W } & 1.0 & 1000 \\ \text { Pu-242 } & \text { W } & 52.0 & 52000 \\ \text { Am-241 } & \text { W } & 1.1 & 1100 \\ \text { Am-243 } & \text { W } & 1.0 & 1000 \\ \text { Cm-242 } & \text { W } & 1.0 & 29000 \\ \text { Cm-244 } & \text { W } & 29.0 & 1900 \\ C f-252 & \text { Y } & 1.9 & 3500\end{array}$

*(D) Daily (W) Weekly (Y) Yearly 
To determine if a waste package with several radionuclides does not exceed $1000 \mathrm{Ci} \mathrm{Pu-239}$ equivalent, the following formula is used:

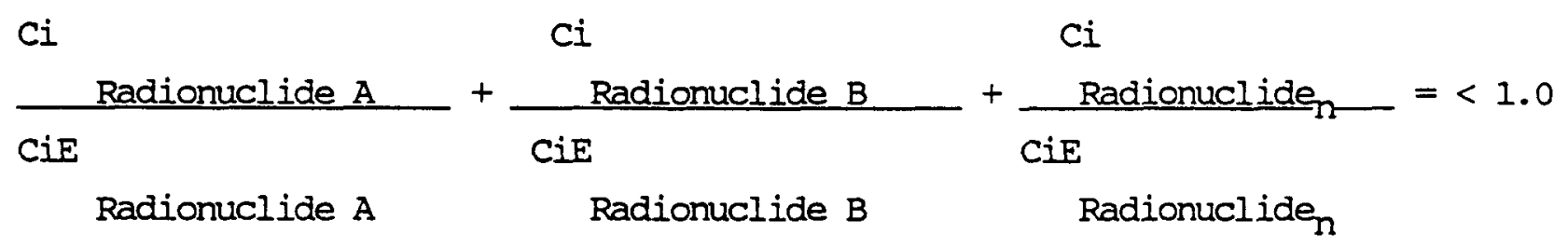

No estimate of non-TRU radionuclides, except those within the scope of the above description, will be included. However, generators will be asked to characterize any waste stream which contains an unusually high Sr-90 content relative to normal fission product isotopic distribution.

\subsection{CRITERION: SURFACE DOSE RATE}

\subsubsection{Contact-Handled Waste}

Waste packages shall have a maximm surface dose rate at any point no greater than $200 \mathrm{mRem} / \mathrm{hr}$. Neutron contributions of greater than $20 \mathrm{mRem} / \mathrm{hr}$ to the total package dose rate shall be reported separately in the data package.

\subsubsection{Remote-Handied Waste}

$\mathrm{RH}$ IRU waste packages shall have a surface dose rate at any point no greater than $1000 \mathrm{Rem} / \mathrm{hr}$. Neutron contributions are limited to $270 \mathrm{mRem} / \mathrm{hr}$. Neutron contribution of greater than $20 \mathrm{mRem} / \mathrm{hr}$ to the total package dose rate shall be reported in the data package. WIPP prior approval is required before RH TRU canisters with a dose rate in excess of 100 Rem/hr but less than 1000 Rem/hr may be shipped to the WIPP.

\subsubsection{Technical Justification}

The WIPP design for the $\mathrm{CH}$ waste handling facility is a large throughput warehouse-type facility that will unload over-the-road transportation containers of their $\mathrm{cH}$ waste package contents and palletize the packages onto standardized WIPP pallets for transfer to the underground level for

$$
-40-
$$


emplacement. The $\mathrm{CH}$ handling personnel will use standard fork trucks and similar handling devices to handle the ch waste packages. A study of dose rates (Reference 11) has shown that unshielded cH personnel at the WIPP would be expected to receive an annual dose of less than $700 \mathrm{mRem}$ if the waste packages handled average about $6 \mathrm{mRem} / \mathrm{hr}$ per package. A dose equivalent of 1 rem/yr has been established as a design goal for waste handling personnel. This is $20 \%$ of the allowable whole-body dose equivalent (5rem/yr).

A shielded storage area is provided in the $\mathrm{CH}$ handling area to store temporarily those cH waste packages which have surface dose rates between 100 and $200 \mathrm{mRer} / \mathrm{hr}$. This will minimize the background radiation level and resulting personnel doses in the $\mathrm{CH}$ palletizing and surge storage area. The WIPP operations will check for neutrons as a matter of policy. Waste packages with significant neutron emissions ( $>20 \mathrm{mRem} / \mathrm{hr}$ ) shall be so noted in the data packages.

All RH waste that will be handled by the WIPP RH handling system must pass through the $\mathrm{RH}$ hot cell in the waste handling building. RH waste packages will pass through the cell upon receipt and then be transferred via a facility cask to the underground level. The facility cask for RH waste is designed to provide adequate personnel shielding of RH waste packages with surface dose rates up to $1000 \mathrm{Rem} / \mathrm{hr}$ (Reference 12). The $1000 \mathrm{Rem} / \mathrm{hr}$ is a maximu which allowed the design of a facility cask that provides for adequate personnel shielding and complies with the rated capacity of the waste hoist. $\mathrm{RH}$ waste packages are limited to neutron emissions of no greater than $270 \mathrm{mRem} / \mathrm{hr}$. Neutron contribution of greater than $20 \mathrm{mRem} / \mathrm{hr}$ to the total package dose rate must be so noted in the data package.

WIPP approval for shipments of RH waste with surface dose rates greater than $100 \mathrm{Rem} / \mathrm{hr}$ is required because storage capacity for these packages is limited to $5 \%$ of total $\mathrm{RH}$ emplacements. 


\subsection{CRITERION: SURFACE CONTAMINATION}

\subsubsection{Contact-Handled Waste}

CH TRU waste packages or package assemblies shall have a removable surface contamination no greater than 50 picocuries per $100 \mathrm{~cm}^{2}$ for alpha-emitting radionuclides and 450 picocuries per $100 \mathrm{~cm}^{2}$ for beta-gamma-emitting radionuclides.

\subsubsection{Remote-Handled Waste}

RH TRU waste packages shall have a removable surface contamination no greater than 50 picocuries per $100 \mathrm{~cm}^{2}$ for alpha-emitting radionuclides and 450 picocuries per $100 \mathrm{~cm}^{2}$ for beta-garma-emitting radionuclides.

\subsubsection{Technical Justification}

Surface contamination levels for shipping packages are delineated in 49 CFR 173.443 for radioactive materials intended for over-the-road transport. These levels are considered by DOT to be adequate for transportation. However, for high-throughput facilities such as the WIPP, even these levels can result in a buildup of contamination levels within the facility over a period of time that will require significant decontamination efforts. This holds true for all aspects of the system, including the possible buildup of contamination within transportation packagings and vehicles.

Experiences in the Naval Nuclear program have shown that facilities can be maintained "clean" if removable alpha-contamination levels are kept at or below 50 picocuries/100 $\mathrm{cm}^{2}$ and removable beta-gamma contamination at or below 450 picocuries $/ 100 \mathrm{~cm}^{2}$. Experience has also shown that these levels are readily achievable.

The WIPP facility design in the $\mathrm{CH}$ area is basically a large open warehouse-type building that will receive, palletize, and deliver loaded pallets of $\mathrm{cH}$ waste packages to the waste hoist for transfer to the underground 
level. The $\mathrm{CH}$ facility will handle between 20 - to 30-thousand $\left(5 \times 10^{5} \mathrm{ft}^{3}\right.$ ) individual $\mathrm{CH}$ waste packages in a year (design basis Reference 3). At this throughput, contamination buildup using the DOT limits would be a problem.

The RH waste in the WIPP, 250 canisters/yr $\left(7,500 \mathrm{ft}^{3} / \mathrm{Yr}\right)$, will be handled using the RH facility hot cell and the facility transfer cask. The goal of the design is to maintain these facilities in an essentially "clean" condition so that needed maintenance can be performed "hands-on" to the greatest extent possible. For this reason, contamination levels should be as low as possible.

The DOT requirements in 49 CFR 173 must be met for TRU waste that is to be shipped over the public highways and rails. However, to prevent the buildup of contamination levels in WIPP facilities and throughout the waste system, contamination levels are required to be even lower.

\subsection{CRITERION: THERMAL POWER}

\subsubsection{Contact-Handled Waste}

Individual $C H$ TRU waste packages in which the average thermal power density exceeds 0.1 watt $/ \mathrm{ft}^{3}\left(3.5 \mathrm{w} / \mathrm{m}^{3}\right)$ shall have the thermal power recorded in the data package.

\subsubsection{Remote-Handled Waste}

The thermal power generated by waste materials in any RH TRU waste package shall not exceed 300 watts. The thermal power shall be recorded in the data package.

\subsubsection{Technical Justification}

Thermal power generation within TRU waste packages due to nuclear decay is of concern both because it can cause package failure from waste decomposition 
and gas formation and, in the case of high levels of heat generation, can cause changes in the isolation medium, such as salt.

Thermal analyses of WIPP-type generic repositories have been performed (Reference 13) that show that more than $150 \mathrm{~kW}$ of heat-generating waste can be emplaced in an acre of a storage facility without unacceptable impacts on the salt beds or the surrounding enviroment. As a conservative design basis for the WIPP, a reduced limit of $10 \mathrm{~kW}$ per acre has been chosen.

The emplacement density of $\mathrm{CH}$ waste in the WIPP is approximately 72,000 cubic feet of waste per acre. This is based on using the available drift area in a given acre of salt on the $\mathrm{CH}$ horizon with 9-foot high waste arrays, taking no credit for the packing space losses between drums. Using the $10 \mathrm{~kW}$ limit, this would allow an average heat generation of 0.14 watts per cubic foot or 1.0 watts per 55-gallon drum.

The present emplacement plan for RH waste calls for an emplacement density of 70 canisters of waste per acre in conjunction with a room filled with the $\mathrm{CH}$ waste. The calculated maximum internal heat-generation rate of less than 60 watts per canister would contribute only $4.2 \mathrm{~kW}$ per acre.

$\mathrm{CH}$ waste in general has very low heat-generation rates and will not even approach the 10-kW-per-acre limit. However, some inventory control of heat source waste will be maintained to prevent localized hot spots in waste arrays. RH waste could generate up to 300 watts per canister without exceeding the thermal limit for the WIPP because $50 \%$ of all canisters projected for shipment to WIPP will be less than 1 watt each and inventory control of emplacement will prevent exceeding the thermal density limit.

\subsection{CRTTERTON: GAS GENERATION}

\subsubsection{Contact-Handled Waste}

Waste packages containing waste forms known or suspected of gas generation, such that a combination of overpressure and explosive mixtures might damage the container in the long term, shall be provided with an appropriate 
method for pressure relief. Any liner other than plastic bagging shall be provided with positive gas communication to the outer container.

Each TRU waste shipper shall provide the following data for each waste package:

- Total activity (alpha Ci)

- Waste form description (from certification Plan)

- Mass and volume percent of organic content

For purposes of transportation and emplacement (short term), there will be no mixture of gases or vapors in any package which could, through any credible spontaneous increase of heat or pressure, or through an explosion, significantly reduce the effectiveness of the packaging.

\subsubsection{Remote-Handled Waste}

All RH TRU waste canisters shall be vented.

\subsubsection{Technical Justification}

Degradation of TRU wastes potentially produces significant quantities of gas. The possibility that enough gas buildup could occur to pressurize the storage facility and induce fractures in the rock salt has been investigated. The experimental program to quantify these effects is well summarized in Reference 5.

Waste degradation by various mechanisms has been studied and the ranges of gas-generation rates have been determined. Analysis of the storage facility response to gas production requires data on gas flow through rock salt and on the possible deformation of the storage rooms as a response to gas pressure. Laboratory studies of rock salt permeability have been considered along with data from WIPP site borehole tests to establish a realistic data base. Finite difference models were utilized to analyze room response during and after the periods of gas production. Calculated stress states were compared with very 
conservative criteria for the initiation and propagation of fractures. An evaluation of all these considerations was made in the formulation of the criterion for gas-generation materials.

While bacterial degradation of organic material in the waste is thought to offer the potential for a significant gas-generation rate, other sources of gas generation must be considered in determining compliance with this criterion. Radiolytic degradation of some waste matrices also can contribute significant gas generation in the storage array, depending on the activity level in the waste, and the presence of oxidizers and moisture. In addition to contributing to gas generation, radiolysis can produce flammable gas mixtures within the waste container. The possibility of flammable gas mixtures relates to safety of waste handling during emplacement as well as meeting transportation regulations.

operational concerns of a shorter term are not related to storage facility inflation but rather to the production of combustible gases which combined with overpressure might result in release of radioactive materials.

The effects of gas pressurization could be important to the long-term containment of radionuclides in the WIPP. If fractures could be initiated and propagated to regions where fluids are present, water intrusion of the storage facility could follow. In addition, if room closure is restricted (by gas pressure), a horizontal region of higher fluid transmissivity could develop, thereby enhancing the potential for fluid motion through the facility.

The concern for gas generation in the CH TRU waste storage rooms arises from the tightly packed configuration of the waste containers: the areal storage density is about $72,000 \mathrm{ft}^{3} /$ acre $\left(5,000 \mathrm{~m}^{3}\right.$ /hectare) .

RH TRU waste, on the other hand, is emplaced with an areal storage density of only about $1750 \mathrm{ft}^{3} /$ acre ( $125 \mathrm{~m}^{3}$ /hectare); even with worst-case assumptions for gas generation, there is no threat to the integrity of the combined $\mathrm{CH}$ and $\mathrm{RH}$ storage rooms because the increase in storage density is only 3 percent. There is, therefore, no need for a criterion which limits the amount of gas-producing materials in RH TRU waste. 
Theoretical studies of radiolytic, thermal, corrosive, and bacterial degradation of IRU wastes (Reference 5) have indicated that a reference drum containing $60 \mathrm{~kg}$ of organics would produce 5600 moles of gas if complete volatilization (e.g., in combustion) took place. Laboratory data indicate that this potential will never be reached. A more reasonable estimate is that a maximm of 2000 moles of gas per drum could potentially be produced (at a maximum generation rate of about 5 moles/year). It has been observed (Reference 5) that most of the gas is produced by bacterial decomposition of the cellulosic components of the waste.

The response of a sealed storage facility to this empirical gas generation rate has been analyzed using techniques that consider permeation of gas through the rock salt, the pressurization of the open drift, and the deformation of the surrounding rock. Parameters for these calculations are taken from laboratory and field permeability measurements that range from 0.5 to 25 microdarcies, and assumptions of even lower permeabilities, down to 0.05 microdarcy.

Calculations were performed for conditions in which rooms were modeled as rigid voids with 25 percent of original drift volume and for conditions in which rooms were allowed to deform in response to gas pressure. In the former case, with a total gas generation of 2000 moles/drum in 400 years and with a permeability of 0.5 microdarcy, the maximum pressures were $11 \mathrm{MPa}$, or 110 atmospheres. At higher permeabilities, as observed in the field, pressurization was insignificant. Coupling of pressurization with room response indicated that maximum pressures were similar, and that the only impact of the gas generation at 0.5 microdarcy was a delay of full room closure from approximately 100 years to about 800 years. There was no significant delay for permeabilities in the 25-microdarcy range.

The calculations revealed that pressurization did not significantly alter the room volume even at permeabilities as low as 0.05 microdarcy. The gas generation criterion was developed from the relationship between the allowable gas-generation rate in a fixed-volume room (25 percent of original volume) and the effective permeability of the geologic formation, with the restriction that the lithostatic pressure could not be exceeded (the assumption being that 
propagation of existing cracks will occur at pressures above lithostatic) . Using a two-dimensional porous flow model and a permeability value of 0.1 microdarcy, the allowable gas-generation rate was determined to be 5 moles/yr per drum (particularly from bacterial decomposition).

Conservative judgments have been made as to the impact of the uncertainties in the assumed gas-generation rate. It is Sandia's judgment (Reference 5) that the 10 moles per year per cubic meter of storage room volume is unlikely to be exceeded in the WIPP enviroment from wastes meeting these criteria, especially if temperatures are near ambient. It should be noted that no high heat producing waste such as fuel elements will be disposed of in the WIPP and that the limited amount of defense high-level waste which will be emplaced temporarily during the proposed in-situ experimental program will not perturb the temperature of the TRU waste disposal rooms, due to the large separation distance of at least $2600 \mathrm{ft}$.

The values chosen for permeability are taken from state-of-the-art laboratory and field data with resolution capabilities between 0.05 and 0.10 microdarcy. While the measured values ( 0.5 to 25 microdarcies) are considered to be accurate reflections of the actual permeability (under the test conditions), lower values were assumed for conservatism; these lower values of permeability, of course, resulted in higher pressures and longer delayed closures but no potential for fracture. As a final point of discussion, bounding case analysis (Reference 6) indicates that even if the most serious consequences of gas pressurization (i.e., fracture and increased fluid transmissivity) do occur, the effect in terms of dose to affected populations is insignificant. Therefore, for long-term storage consideration, the waste generators need only provide the data specified in the criterion, and this will be handled on an operational basis at the WIPP.

Methods for reducing gas accumulation in the waste package are available. Gas generation rates can be recuced by controlling the total alpha curie loading of dnums containing waste matrices known to produce significant quantities of gases, such as combustibles and sludges. Another method is the possible use of hydrogen getters (recombination catalysts), compounds which selectively react with hydrogen. Finally, gas accumulation can be reduced by 
the use of a suitable vent system on the waste package. The intermal packaging materials may impede the flow of gases to the container vent system, however, and must be evaluated.

Explosive mixtures and container overpressure are addressed in DOT regulations, specifically 49 CFR 173.21(c), 173.24(a)(3), 173.412(h), and $173.475(\mathrm{~h})$. Meeting these shipping requirements will also provide adequate safety consideration to the unloading and emplacement activities at the WIPP.

\subsection{CRITERION: LABEITNG}

\subsubsection{Contact-Handled Waste}

In addition to DOT labeling requirements, each waste package shall be uniquely identified by means of a label permanently attached in a conspicuous location. The package identification number (to be standardized) shall be in medium to low density code 39 barcode symbology per MII-STD-1189 in characters at least 1 inch high, and alphanumeric characters at least 1/2 inch high.

The label must be reasonably expected to remain legible and affixed to the container for a period of 10 years under anticipated conditions of interim storage before shipment to the WIPP and emplacement underground.

\subsubsection{Remote-Handled Waste}

Each waste package shall be uniquely identified by means of an identification number permanently attached to the container in a conspicuous location using characters at least 2 inches high.

The label must be reasonably expected to remain legible and affixed to the container for a period of 10 years under anticipated conditions of interim storage before shipment to the WIPP and emplacement underground. 


\subsubsection{Technical Justification}

Due to the latest mechanized material handling techniques, the only item of $\mathrm{CH}$ data that is of direct, immediate concern to WIPP operating personnel safety is the surface dose rate. This is available from the WIPP data base, but package identification numbers must be used to access this data.

Each package would be assigned a serial number with a prefix unique to the shipping site, and the serial number would be placed both on the waste package and on the data package. The military standard for barcode symbology (Reference 25) is applied because it gives specific criteria for the label properties (i.e. spacing, reflectivity, contrast, etc.), and this requirement defines a uniform symbology for all TRU waste participants.

Since the RH canisters will always be remotely handled, the package serial number must be placed in such a manner as to allow remote reading.

\subsection{CRITERION: DATA PACKAGE/CERTIFICATION}

\subsubsection{Contact-Handled Waste}

There shall be transmitted to the WIPP operator in advance of shipment, a data package/certification attesting to the fact that the waste package meets the requirements of these criteria. This data package/certification shall be based upon a quality assurance program subject to audit and verification and shall provide information on the items specified below:

- Package identification number

- Package assembly identification number (if applicable)

- Date of waste package certification

- WAC exception number (if applicable)

- Waste generation site

- Date of packaging (closure date) 
- Maximm surface dose rate in mRem/hr and specific neutron dose rate if greater than $20 \mathrm{mRem} / \mathrm{hr}$

- Weight (in $\mathrm{kg}$ )

- Container type

- Physical description of waste form (content code)

- Assay information, including $\mathrm{PE}-\mathrm{Ci}$, alpha $\mathrm{Ci}$, and Pu-239 fissile gram equivalent content

- Radionuclide information including radionuclide symbol, quantity, and measure (in grams or curies)

- Radicactive mixed waste (identity and quantity of hazardous waste characteristic[s])

- Weight and volume percent of organic materials content

- Measured or calculated thermal power (if over 0.1 watt/ $\mathrm{ft}^{3}$ )

- Shipment number

- Date of shipment

- Vehicle type

- TRUPACT number(s)

- Other information considered significant by the shipper

- Name of certifying official who certified the waste package

- Name of person who certifies that the shipment meets the TRUPACT Authorized Payload Compliance Plan

A hard copy of the signed and dated certification statement, certifying that the waste content and packaging are in accord with the WIPP-WAC and that the waste is unclassified, shall be maintained on file at each site for WACCC audits.

\subsubsection{Remote-Handled Waste}

There shall be transmitted to the WIPP operator in advance of shipment, a data package/certification attesting to the fact that the waste package meets the requirements of these criteria. This data package/certification shall be 
based upon a quality assurance program subject to audit and verification and shall provide information on the items specified below:

- Package identification number

- Date of waste package certification

- WAC exception number (if applicable)

- Waste generation site

- Date of packaging (closure date)

- Maximm surface dose rate in Rem/ $\mathrm{hr}$ and neutron dose rate in $\mathrm{mRem} / \mathrm{hr}$, if greater than $20 \mathrm{mRem} / \mathrm{hr}$

- Weight (in $\mathrm{kg}$ )

- Internal container type

- Physical description of waste form (content code)

- Assay information, including $\mathrm{PE}-\mathrm{Ci}$ and $\mathrm{Pu}-239$ fissile gram equivalent content

- Radionuclide information including radionuclide symbol, quantity, and unit of measure (in grams or curies)

- Radioactive mixed waste (identity and quantity of hazardous waste characteristic(s))

- Measured or calculated thermal power

- Shipment number

- Date of shipment

- Vehicle type

- Cask number

- Other information considered significant by the shipper

- Name of certifying official who certified the waste package

- Name of person who certifies that the shipment meets the TRUPACT Authorized Payload Compliance Plan

A hard copy of the signed and dated certification Statement, certifying that the waste content and packaging are in accord with the WIPP-WAC and that the waste is unclassified, shall be maintained on file at each site for WACCC audits. 


\subsubsection{Technical Justification}

With the first-of-a-kind pilot facility such as the WIPP, it is important that all pertinent parameters that affect the design and safety analyses, such as thermal power generation, nuclide contents, gas generation, combustibility, toxic potential, etc., be known and documented. The WIPP will have to maintain strict inventory controls on waste emplacements in order to ensure that technical specifications are adhered to and that the plant is operated within established limits. Also, WIPP must annually report its radionuclide inventory to the Integrated Data Base. The retrievability requirements of the WIPP also require that adequate permanent records of inventory and emplacement histories are kept to ensure safe operation of future recovery efforts that may occur a few years after actual emplacement. The format for data transmitted to WIPP is defined in WIPP-DOE-157.

The actual implementation of the inventory control system will be the responsibility of the WIPP operator. However, the information required by the system must be supplied by the waste generators and shipping sites.

CH data that are of direct, immediate concern to operating personnel safety would be surface dose rate and weight. Additional data required by these criteria, of concern to facility personnel, must be provided in a separate data package for each shipment.

Inventory control and long-term safety considerations require information on nuclide contents, the waste generating site, date of packaging, container type and certification, physical description of the waste form, assay information, hazardous materials (nonradionuclide), percent of organics and gas generators, thermal power, date of shipment, any other data the shipper may have that is significant, etc. (see listings in the criteria). All of these data, if appropriate, are provided for each package shipped to the WIPP. The radionuclide contents may be reported using quantities of approved isotopic mixtures. Isotopic mixtures currently used by the solid Waste Information Management System (SWIMS) are acceptable to WIPP. New isotopic mixtures will require approval by WIPP prior to being acceptable in the data package. For waste that is precertified and transshipped to another site for interim 
storage, the waste package certification date provided in the data package should be the original or precertification date. Each package is assigned a serial number with a prefix unique to the shipping site, and the serial number is placed both on the waste package and on the data package.

The DOE Order 5820.2A, Chapter II.3.h.3, requires that the data package be validated before the waste is shipped to WIPP. Routinely the shipper will transmit the data package to the WWIS, which performs edit and range checks and then either informs the shipper of the errors detected or that the data package was entered into the WwIs. If this is not possible due to communications or computer downtime, the data package must be faxed to WIPP during day shift Mountain Time for manual validation and notification of the shipper.

The WIPP data and computer will be directly tied to all waste generation and shipping sites so that data packages for waste shipments can be transmitted directly to the WIPP prior to shipment release from the site. This will allow the WIPP to make any needed adjustments to inventory or emplacement plans or to implement special safety procedures prior to receipt at the WIPP. WIPP Quality Assurance also needs the name of the individual who transmits the data package so that any questions regarding verification of the data can be addressed.

After WIPP is declared a repository, a generator/shipper may request that WIPP accept a waste package that does not meet the WAC. This will be done using an approved WIPP procedure, and WIPP will assign a WAC Exception Number to that request until it is either disapproved or is approved and the waste is shipped.

$\mathrm{RH}$ documentation requirements will be similar to $\mathrm{CH}$ with the exception of the weight percent of organic material present in the waste.

Extensive data and inventory control will be required for all wastes emplaced in the WIPP to ensure safe operation within operational safety requirements. 


\subsection{CRITERTON: RH TRU ACIIVITY CONCENIRATION}

\subsubsection{Remote-Handled Waste}

The maximm activity concentration for a RH TRU waste package shall not exceed 23 aries/liter. The concentration may be averaged over the waste container.

\subsubsection{Technical Justification}

This criterion arises from the WIPP Final Envirommental Irpact Statement (Reference 6). 


\subsection{REFERENCES}

1. WIPP-DOE-069, "Report of the Steering Committee on TRU Waste Acceptance Criteria for the Waste Isolation Pilot Plant, May 1980.

2. DOE/RW-0006, "Spent Fuel and Radioactive Waste Inventories, Projections and Characteristics," Updated Annually.

3. WIPP-DOE-71, Rev. 3, Design Criteria, "Waste Isolation Pilot Plant Revised Mission Concept-IIA," December 1982.

4. ANSI/ANS-8.15-1981, "American National Standard for Nuclear Criticality Control of Special Actinide Elements.

5. Report SAND79-1305, "Summary of Research and Development Activities in Support of Waste Acceptance Criteria for Waste Isolation Pilot Plant," Sandia Laboratories, November 1979.

6. FEIS DOE/EIS-0026, "Final Enviromental Impact Statement, Waste Isolation Pilot Plant," U. S. Department of Energy, October 1980.

7. Report LA-7674-MS, "Gas Generation from Radiolytic Attack of TRU-Contaminated Hydrogenous Waste," Ios Alamos Scientific Laboratory, June 1979.

8. Report, "Modeling Verification Studies, Iong Term Waste Isolation Assessment, Waste Isolation Pilot Plant Project, Southeastern New Mexico," D'Appolonia, January 1981.

9. Task Group on Iung Dynamics, Health Physics 12, 173-207 (1966) and Health Physics 13 1251, (1967).

10. Report FET898-74-116, "Plutonium in Oxide to be Shipped to the Savannah River Plant," Rocky Flats Plant, March 1974.

11. WTSD-TME-009, "Preliminary Radiation Dose Assessment to Waste Isolation Pilot Plant Waste Handling Personnel," February 1985.

12. WISD-TME-041, "Horizontal Emplacement and Retrieval Equipment Detailed Design Report," December 1984.

13. Report Y/OWI/SUB-76/07220, "The Selection and Evaluation of Themal Criteria for a Geologic Waste Isolation Facility in Salt, " Office of Waste Isolation, September 1976.

14. "First Modification to the July 1, 1981, 'Agreement for Consultation and Cooperation' on Waste Isolation Pilot Plant by the State of New Mexico and US Department of Energy," November 30, 1984.

15. DOE/WIPP 88-014, "Criticality Safety Analysis for Contact Handling Waste at the Waste Isolation Pilot Plant," May 1988. 
16. DOE/WIPP 88-020, "Criticality Safety Analysis for Remote Handled TRU Waste the Waste Isolation Pilot Plant," July 1988.

17. DOE/WIPP 87-014 (formerly WISD-TME-062), "Assessment of Allowable Transuranic Activity Iimits for Waste Isolation Pilot Plant Waste," December 1987.

18. Reconmendations of the International Commission on Radiological Protection, ICRP Publication 26, January 1977.

19. Iimits for Intakes of Radionuclides by Workers, ICRP Publication 30, July 1978.

20. USDOE Memorandum, April 25, 1985, R. W. Earl (Acting Director, Real Property and Facilities Management Division, Office of Project and Facilities Management) to C. N. Mitchell (Director, Office of Project and Facilities Management) Radiological Siting Requirements DOE Order 6430.1, General Design Criteria, dated 12-12-83.

21. WIPP-DOE-176, Revision 1, "Estimates of Intermal Dose Equivalent from Inhalation and Ingestion of Selected Radionuclide," Donald E. Dunning.

22. DOE/DP/00058-HI; MIM 3245, "DOE Emulation Document for DOT 7A Type A Packaging," March 1987.

23. DOE Order 5820.2A "Radicactive Waste Management," September 1988.

24. RHO-RE-MA-7 "User's Manual for Remote-Handle Transuranic Waste Containers," September 1984.

25. MII-STD-1189 "Military Standard - Standard Department of Defense Barcode Symbology", as updated. 


\section{MISSION AND DESCRIPTION OF WIPP}

The primary mission of the WIPP is to emplace in bedded salt the particular type of radioactive waste called defense transuranic (TRU) waste: material contaminated with chemical elements heavier than uranium from defense programs.

The U.S. defense program has already generated large quantities of CH TRU waste, which requires no shielding, and RH TRU waste, which requires shielding to protect workers who handle it.

Before 1970, waste containing TRU nuclides was not segregated from other waste contaminated with low levels of radioactivity. Therefore, a large volume of material now considered CH TRU waste was buried in a manner similar to conventional sanitary landfill operations, with additional handling precautions appropriate for radioactive materials. The-waste was placed in open unlined trenches and then covered with several feet of earth. At the time of its burial, this waste was not intended to be retrieved.

In 1970, the U.S. Atomic Energy Commission changed its regulations to require wastes with known or detectable contamination of transuranium nuclides to be packaged and buried in such a fashion that they can be readily retrievable as contamination-free packages within an interim period of 20 years (USAEC Immediate Action Directive 0511-21, "Policy Statement Regarding Solid Waste Burial," March 20, 1970). Later in 1973, the Atomic Energy Commission defined transuranium solid wastes to be placed in retrievable storage as, "Those wastes with certain alpha-emitting radionuclides of long half-life and high specific radiotoxicity to greater than $10 \mathrm{nCi} / \mathrm{g} . . . "$ (ERDA Manual, Chapter 0511-011.) In 1984, DOE Order 5820.2 redefined TRU contaminated material; that definition is included in Section 3.0 . 
Remote-handled TRU waste has always been handled separately. Much of it has been put into 1 to 2-foot diameter pipes placed vertically in the ground, with a shielding plug at the top of each pipe. Other waste of this type has been placed in large shielded containers that reduce the radiation level at the exterior surface to relatively low levels.

At the end of 1987, the accumulated volume of TRU waste (buried and retrievably stored) amounted to an estimated 10 million cubic feet of material (not including contaminated soil estimates) containing 1250 kilocuries of alpha radioactivity, only 3.3 million cubic feet ( 1140 kilocuries) of which was readily retrievable. It is anticipated that 1.2 million cubic feet of the TRU waste currently in retrievable storage will be redesignated as low level waste. About 49,000 cubic feet of RH TRU waste from defense programs is now in storage (Reference 2).

The rate at which contact-handled TRU waste is produced is now about 0.11 million cubic feet per year. The WIPP is designed to handle a maximum of 0.5 million cubic feet of $\mathrm{CH}$ waste per year on a one shift per day, 5-day week basis. Thus, if the WIPP were to start accepting waste in FY 1989, the easily retrieved and newly generated waste could be placed in deep underground storage in 13 years, by 2002. However, other factors such as the transportation system and current staffing level will limit the throughput to about 0.22 million cubic feet per year.

In addition to the current and projected volumes, the WIPP could receive some TRU waste from operations such as the dismantling and decontamination of obsolete and no-longer-needed weapons-production facilities. Estimates of the volume of such waste range from 5 to 95 million cubic feet. The amount of such waste that could be stored at the WIPP is limited by the total authorized TRU storage area of approximately 100 acres, which has an estimated capacity of 6.2 million cubic feet.

In summary, the primary need that has led to the proposal for the WIPP is to remove this large quantity of existing defense-generated waste from surface 
storage and to isolate it from the biosphere in a manner that will be acceptable for the indefinite future.

The area in the WIPP set aside for potential underground storage operations is about 2000 acres; the remaining acreage will provide a buffer zone around the underground operations area. The excavation at the storage level will provide about 100 acres for waste disposal. There will be a separate area of about 10 acres for waste experimentation. Service areas will take up small additional acreage.

Because the WIPP will be the first bedded-salt waste research and development facility, the waste will be emplaced in such a manner that it can be retrieved from its place of burial if removal becomes necessary. At a future time, after further tests and analyses, a final decision will be made on whether to leave the waste emplaced permanently. The WIPP is designed on the expectation that this decision on permanent emplacement will be made for the TRU waste after successful demonstration of safe waste disposal of each species ( $\mathrm{CH}$ and $\mathrm{RH}$ ). This demonstration will last up to five years from the initial emplacement of waste. It is anticipated that retrieval could take up to 10 years if the decision for retrieval is made.

The WIPP is designed to receive nuclear waste materials in protective packages, prepare them for underground storage, transport them to the salt bed storage locations, and provide retrievable storage.

The annual quantity of $\mathrm{CH}$ waste for which the WIPP has been designed is 0.5 million $\mathrm{ft} 3 / \mathrm{yr}$ or one shift operation (Reference 3 ), the majority of which will arrive in 55-gallon drums banded together in seven-packs; 4 $\times 4 \times 7 \mathrm{ft}$ and other metal boxes. Accommodations are provided for both rail and truck shipments. The quantity of RH waste anticipated is approximately $7,500 \mathrm{ft} 3 / \mathrm{yr}$. All RH waste will be contained within shipping casks. 
The overall plot plan for the WIPP is shown in Figure A-1. The truck, semi-trailers, and railroad cars are delivered inside the WIPP boundary and parked in the areas identified in Figure A-1. When these shipments are received, they will be surveyed for external contamination. Any containers found with external contamination in excess of established limits as defined in these criteria will undergo decontamination.

A schematic flow diagram for $\mathrm{CH}$ waste is shown in figure $\mathrm{A}-2$. The diagram shows the major steps involved in the receipt, inspection, handling, and emplacement of the waste. Retrieval of $\mathrm{CH}$ waste is essentially just a reversal of the emplacement flow.

The RH waste emplacement schematic flow diagram is shown in Figure A-3. The diagram shows the major steps involved in cask handling, hot cell operation, facility cask transfer operations, and underground transporter and emplacement operations. Remote-handled retrieval from sleeved holes is simply the reverse of the emplacement procedure.

The basic underground development of the WIPP is shown in Figure A-4. The WIPP underground environment during operation will be an average ambient temperature of $820 \mathrm{~F}(280 \mathrm{C})$ and an average relative humidity of less than 40 percent. The composition of the salt is approximately-97 percent halite with the remainder made up mainly of anhydrite. 


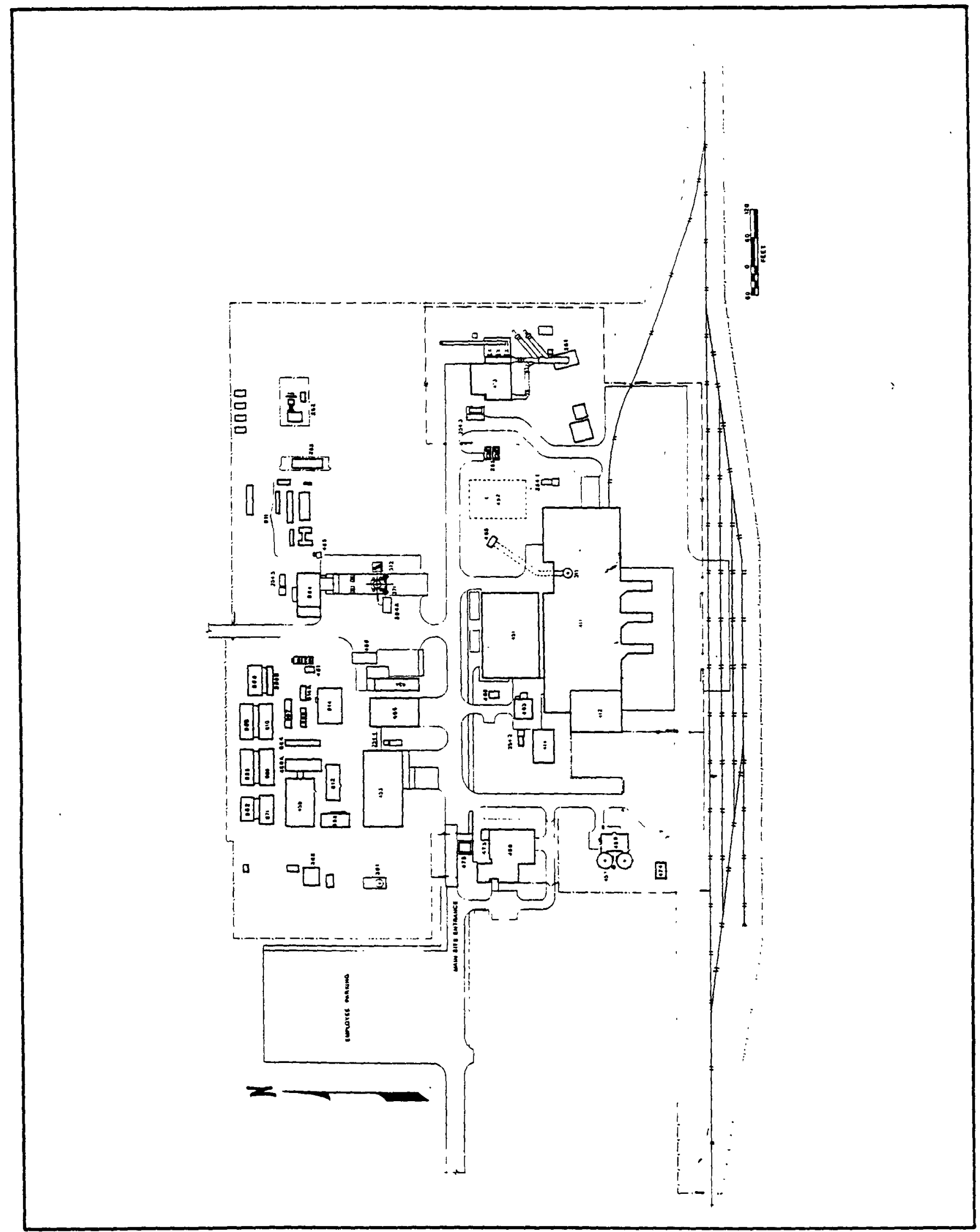

FIGURE $A-1$

Surface Structures and

Plant Layout

FAE18 6.2 


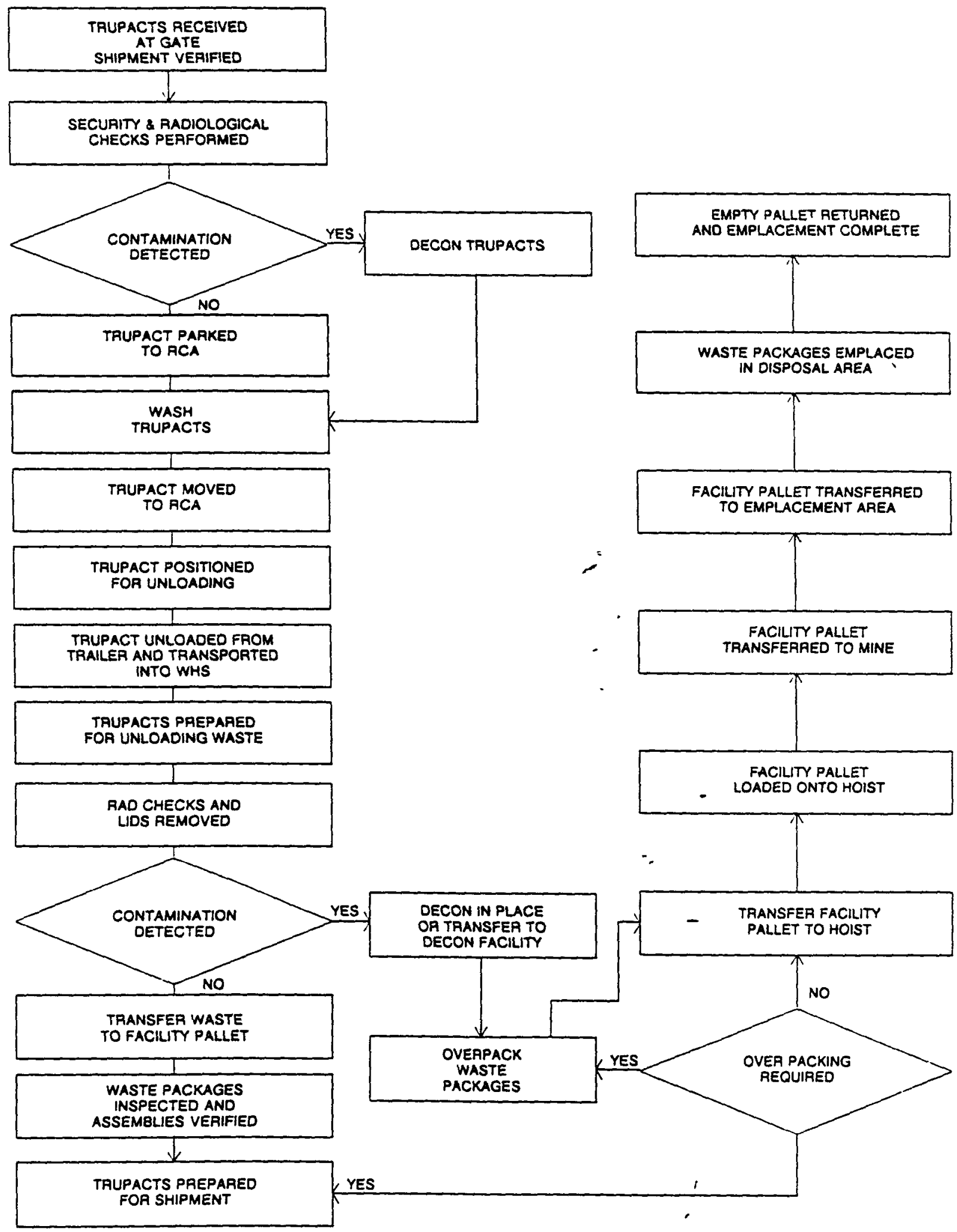

FIGURE A-2

CH Emplacement Flow Diagram 


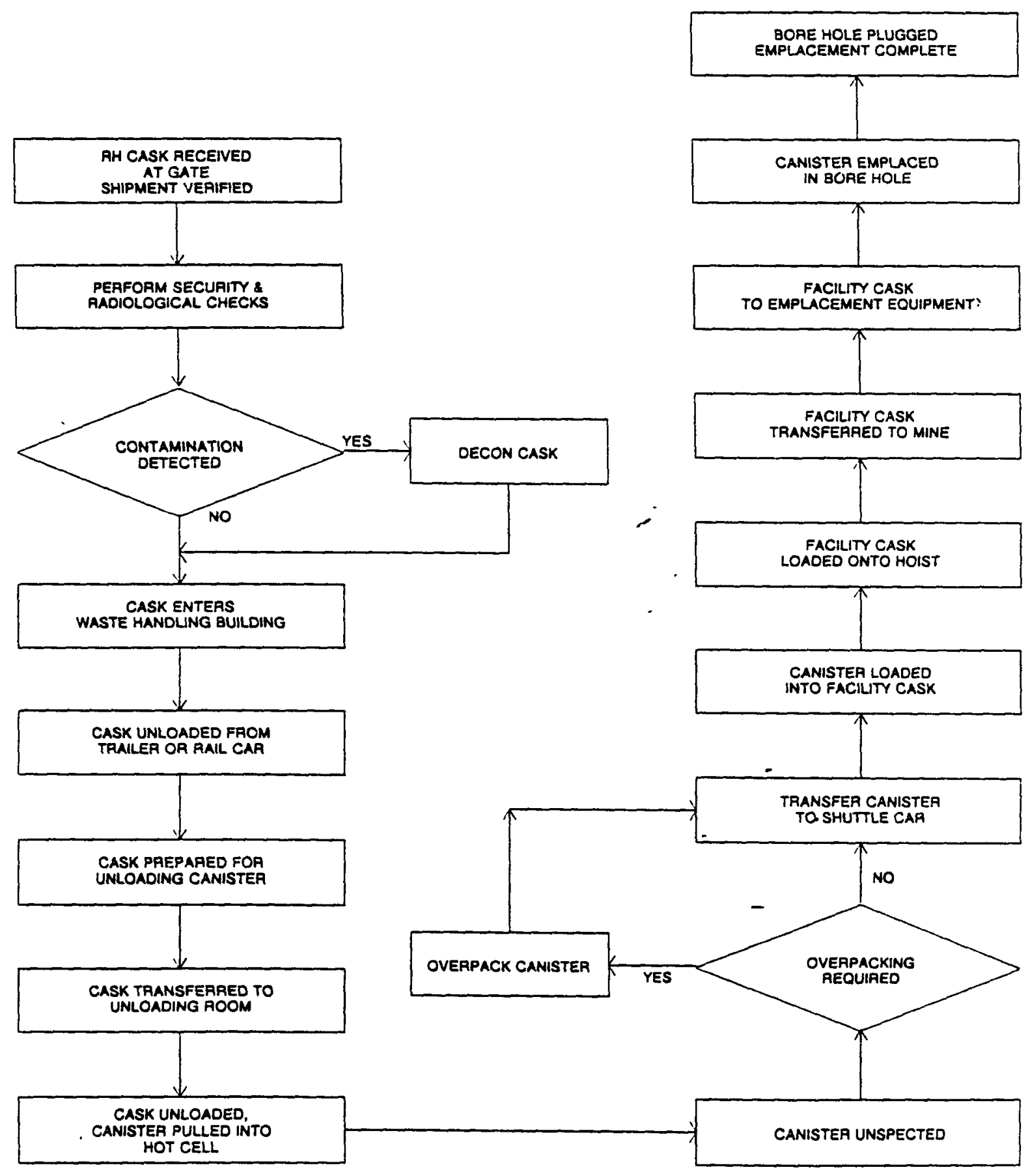

FIGURE $A-3$

RH Emplacement

Flow Diagram

WAH168.1 


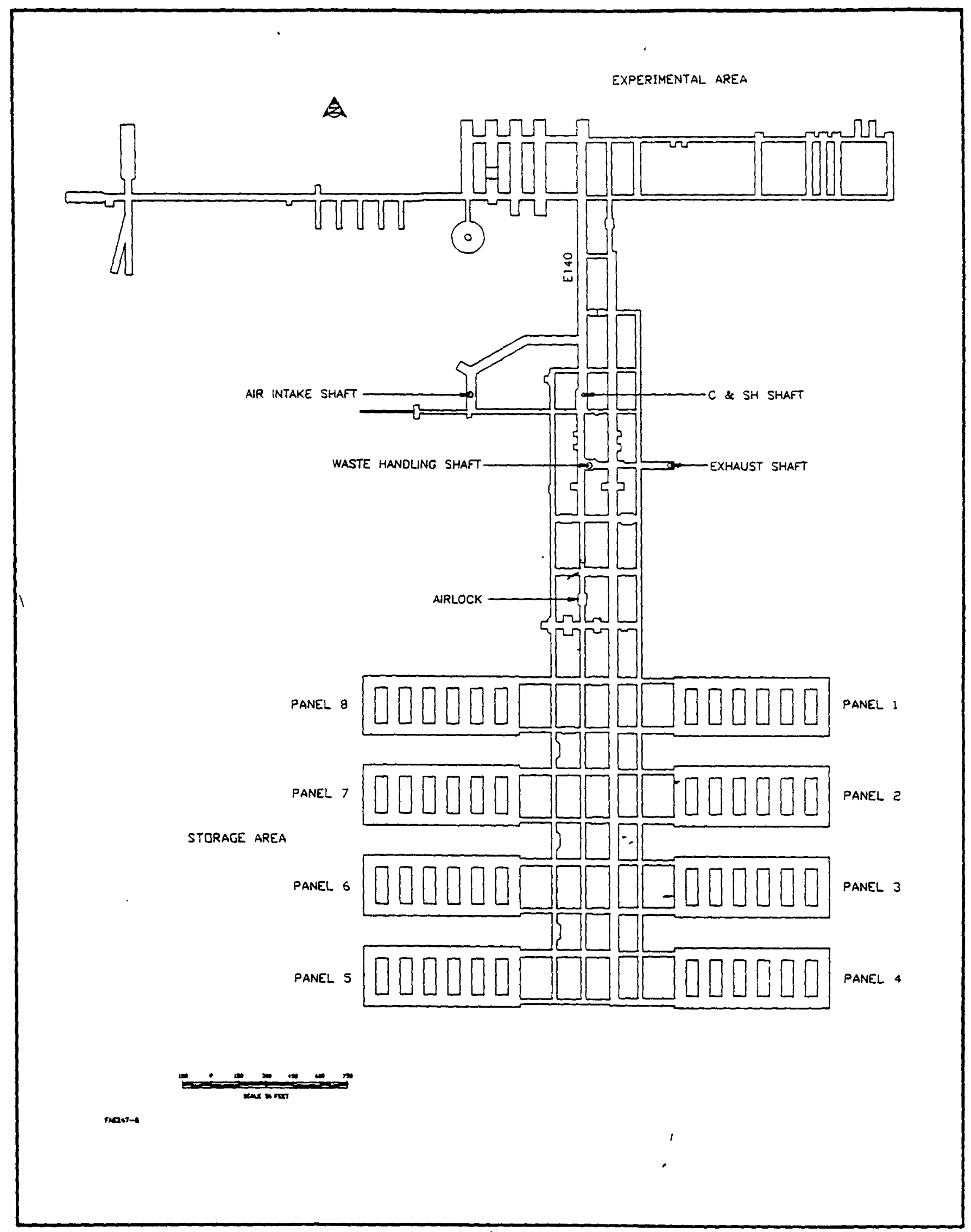

FIGURE A-4 